\title{
Macrofaunal assemblages from mud volcanoes in the Gulf of Cadiz: abundance, biodiversity and diversity partitioning across spatial scales
}

\author{
M. R. Cunha ${ }^{1}$, C. F. Rodrigues ${ }^{1}$, L. Génio ${ }^{1}$, A. Hilário ${ }^{1}$, A. Ravara ${ }^{1}$, and O. Pfannkuche ${ }^{2}$ \\ ${ }^{1}$ Departamento de Biologia \& CESAM, Universidade de Aveiro, Aveiro, Portugal \\ ${ }^{2}$ GEOMAR, Helmholtz Centre for Ocean Research, Kiel, Germany \\ Correspondence to: M. R. Cunha (marina.cunha@ua.pt)
}

Received: 21 November 2012 - Published in Biogeosciences Discuss.: 17 December 2012

Revised: 14 March 2013 - Accepted: 23 March 2013 - Published: 17 April 2013

\begin{abstract}
The Gulf of Cadiz is an extensive seepage area in the south Iberian margin (NE Atlantic) encompassing over 40 mud volcanoes (MVs) at depths ranging from 200 to $4000 \mathrm{~m}$. The area has a long geologic history and a central biogeographic location with a complex circulation ensuring oceanographic connectivity with the Mediterranean Sea, equatorial and North Atlantic regions. The geodynamics of the region promotes a notorious diversity in the seep regime despite the relatively low fluxes of hydrocarbonrich gases. We analyse quantitative samples taken during the cruises TTR14, TTR15 and MSM01-03 in seven mud volcanoes grouped into Shallow MVs (Mercator: $350 \mathrm{~m}$, Kidd: 500 m, Meknès: 700 m) and Deep MVs (Captain Arutyunov: 1300 m, Carlos Ribeiro: 2200 m, Bonjardim: 3000 m, Porto: $3900 \mathrm{~m}$ ) and two additional Reference sites (ca. $550 \mathrm{~m}$ ). Macrofauna (retained by a $500 \mu \mathrm{m}$ sieve) was identified to species level whenever possible. The samples yielded modest abundances (70-1567 individuals per $0.25 \mathrm{~m}^{2}$ ), but the local and regional number of species is among the highest ever reported for cold seeps. Among the 366 recorded species, 22 were symbiont-hosting bivalves (Thyasiridae, Vesicomyidae, Solemyidae) and tubeworms (Siboglinidae). The multivariate analyses supported the significant differences between Shallow and Deep MVs: The environmental conditions at the Shallow MVs make them highly permeable to the penetration of background fauna leading to high diversity of the attendant assemblages $\left(H^{\prime}: 2.92-3.94 ; \mathrm{ES}_{(100)}: 28.3-45.0\right.$; $J^{\prime}:$ 0.685-0.881). The Deep MV assemblages showed, in general, contrasting features but were more heterogeneous $\left(H^{\prime}: 1.41-3.06 ; \mathrm{ES}_{(100)}: 10.5-30.5 ; J^{\prime}: 0.340-0.852\right)$ and of-
\end{abstract}

ten dominated by one or more siboglinid species. The rarefaction curves confirmed the differences in biodiversity of Deep and Shallow MVs as well as the convergence of the latter to the Reference sites. The Bray-Curtis dissimilarity demonstrated the high $\beta$-diversity of the assemblages, especially in pairwise comparisons involving samples from the Deep MVs. Diversity partitioning assessed for species richness, Hurlbert's expected number of species and ShannonWiener index confirmed the high $\beta$-diversity across different spatial scales (within MVs, between MVs, between Deep and Shallow MVs). We suggest that historical and contemporary factors with differential synergies at different depths contribute to the high $\alpha$-, $\beta$ - and $\gamma$-diversity of the mud volcano faunal assemblages in the Gulf of Cadiz.

\section{Introduction}

After only a few decades since the discovery of cold seeps and their associated faunal assemblages (Paull et al., 1984; Suess et al., 1985; Juniper and Sibuet, 1987), it is now well established that these are immensely diverse and widely distributed reducing marine environments spanning from coastal to hadal depths in different geological settings of passive and active margins (e g. Levin, 2005; Cordes et al., 2010b; Levin and Sibuet, 2012). Accumulated knowledge faded the distinction between hydrothermal vents and cold seeps which are evermore considered to exhibit a continuum of abiotic and biotic characteristics (Levin et al., 2012). In this context it becomes increasingly important to differentiate 
the intricate effects of water depth and relevant changes in the oceanographic and geologic settings in the composition and structure of biological assemblages from reducing environments.

Along the European Atlantic and Mediterranean margins, there are three main regions characterized by the presence of seep-related structures (e.g. mud volcanoes, pockmarks, brine pools): the Nordic margin, the south Iberian region and the eastern Mediterranean (Foucher et al., 2009; Vanreusel et al., 2009). The south Iberian region, probably the one that has been less systematically investigated, in fact also encompasses the Moroccan margin and it is a complex of two distinct but tectonically and oceanographically related areas the Alboran Sea (West Mediterranean), and the Gulf of Cadiz (NE Atlantic). Evidence for the presence of Jurassic oceanic crust in the central Gulf of Cadiz (Sallarès et al., 2011) indicates that the geologic history of the region is probably one of the most ancient in the NE Atlantic. The geodynamic setting is determined by two plate-driving mechanisms: (i) subduction (West Mediterranean) associated with the formation of an accretionary wedge (Gulf of Cadiz) which is thought to be inactive at present and (ii) oblique collision between Iberia and Nubia, presently active and causing thrusting and dextral wrenching along the Azores-Gibraltar fault zone (Zittelini et al., 2009). The present oceanographic setting is dominated by the exchanges through the Strait of Gibraltar (Ambar et al., 2002) and the Gulf of Cadiz is characterized by the formation of meddies and recirculation of the Mediterranean Outflow Water. This intermediate layer between the surface and the central North Atlantic water masses interacts with the seafloor at the upper slope (Quentel et al., 2011), while in the deeper western regions there is evidence for input of high-nutrient Antarctic Intermediate Water (Van Aken, 2000). These interactions are reflected in varying sea bottom current velocities and temperatures (from $4{ }^{\circ} \mathrm{C}$ at the deeper locations and up to $13{ }^{\circ} \mathrm{C}$ if under the influence of the Mediterranean Outflow Water).

It is now well established that mud volcanism and other processes associated with the escape of hydrocarbon-rich fluids in the Gulf of Cadiz sustain a broad diversity of chemosymbiotic organisms (Rodrigues et al., 2008, 2013; Hilário and Cunha, 2008; Hilário et al., 2010; Oliver et al., 2011). This extensive seepage area encompasses over 40 mud volcanoes that pierce the accretionary wedge at depths ranging from 200 to $4000 \mathrm{~m}$. Flow rates are relatively low $\left(0.05-15 \mathrm{~cm} \mathrm{yr}^{-1}\right.$; Hensen et al., 2007; Vanneste et al., 2011), and major active mud volcanoes are located along strike-slip faults (Pinheiro et al., 2003) which constitute a feeder system, acting as main upward conduits for the deep-sourced overpressurized fluids and hydrocarbon gases. The deep hydrothermal alteration of basement rocks of the ocean-continent transition crust may be involved in the production of these fluids (Nuzzo et al., 2009). Although predominantly deep and thermogenic (Stadnitskaia et al., 2006; Hensen et al., 2007; Nuzzo et al., 2009), different sources of methane and transport processes determine a highly variable pore fluid geochemistry at different mud volcanoes (Niemann et al., 2006; Nuzzo et al., 2009; Scholz et al., 2009, 2010), and even at different locations of a single mud volcano (Sommer et al., 2009; Vanneste et al., 2011). Even at the deeper mud volcanoes, the fluxes of methane are relatively low (up to $407 \mathrm{mmol} \mathrm{m}^{-2} \mathrm{yr}^{-1}$, Niemann et al., 2006; 0-806 $\mathrm{mmol} \mathrm{m}^{-2} \mathrm{yr}^{-1}$, Vanneste et al., 2011) and its concentrations in surface sediments are in general lower than $0.001 \mathrm{mM}$ (Niemann et al., 2006). The complete depletion of methane and sulfate within the subsurface matches elevated rates of sulfate-dependent anaerobic oxidation of methane $(\mathrm{AOM})$, an efficient microbial filter, and, in some cases, methanotrophic symbiont-hosting invertebrates consume a large proportion of the ascending methane, and directly and indirectly affect methane turnover (Sommer et al., 2009). These environmental setting variations and AOM activity are reflected by diverse microbial community compositions (Vanreusel et al., 2009), and most symbiont-hosting invertebrates in the Gulf of Cadiz are thiotrophic (Rodrigues et al., 2010, 2011a).

The widespread occurrence of massive authigenic carbonate chimneys and crusts typically at depths between 600 and $1200 \mathrm{~m}$ along the margins of Morocco and Spain suggests that this was a very active seepage area in the past (Wehrmann et al., 2011; Magalhães et al., 2012; Vanneste et al., 2012). In these carbonate provinces there are frequent observations of mounds, thickets and debris of mostly dead cold-water scleractinian corals (Wienberg et al., 2009) and also extensive buccinid and mytilid graveyards (usually within the crater of the mud volcanoes).

Here we analyse quantitative samples taken during the cruises TTR14 and TTR15 onboard the RV Prof. Logachev (Kenyon et al., 2006; Akhmetzhanov et al., 2007), and MSM01-03 onboard the RV Maria S. Merian, and describe patterns in biodiversity, abundance and community structure of the benthic macrofaunal assemblages in seven mud volcanoes along a bathymetric gradient in the Gulf of Cadiz. This unique set of mud volcanoes, spanning upper slope to abyssal depths within a single region of the continental margin, provides an ideal framework to investigate: (a) the spatial scales of variability in $\alpha$-and $\beta$-diversity; (b) the influence of the changing environmental conditions with increasing water depth in the macrofaunal assemblages; and (c) the role of chemosymbiotic and heterotrophic species in the composition and structure of the seep assemblages.

\section{Material and methods}

\subsection{Study sites}

The study sites are seven mud volcanoes (MVs) located along a bathymetric gradient ranging approximately from $350 \mathrm{~m}$ to $4000 \mathrm{~m}$ water depths (Fig. 1). 


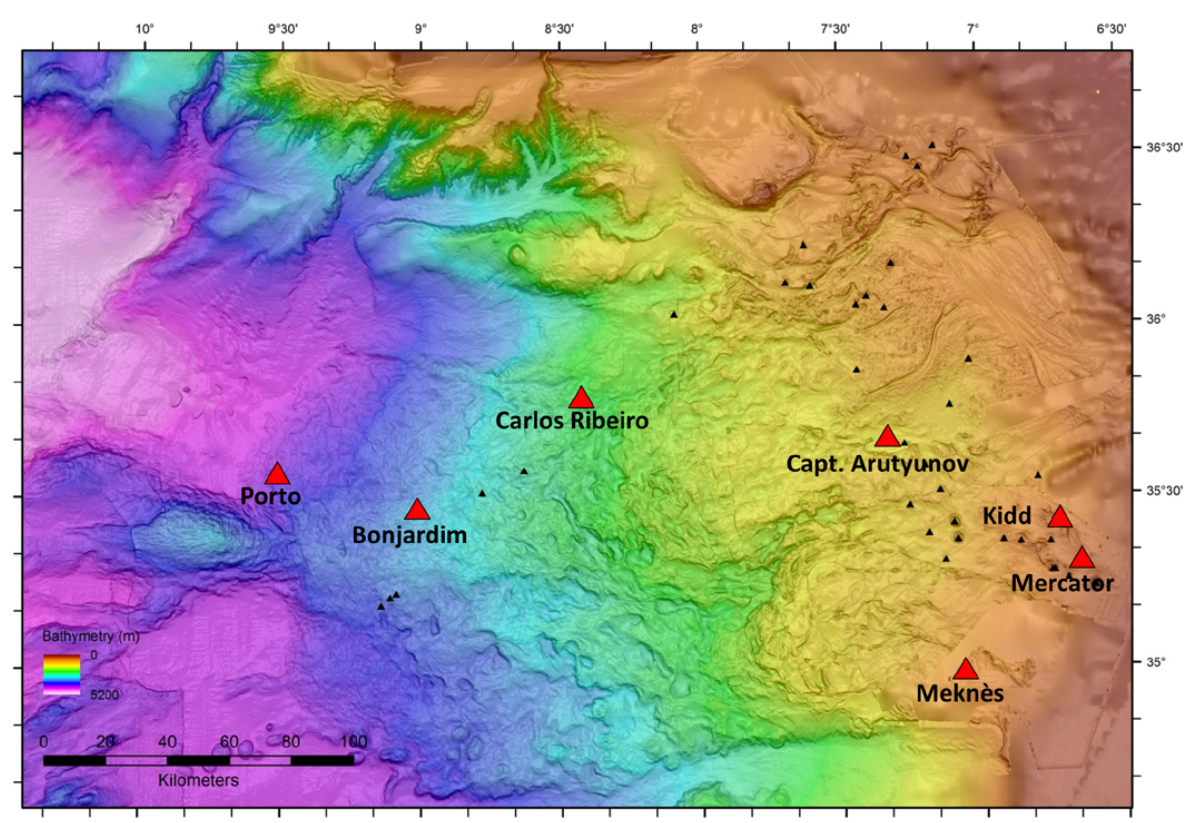

Fig. 1. Map of the study area in the Gulf of Cadiz. Large red triangles: location of the seven studied mud volcanoes; small black triangles: other mud volcanoes in the area; the two reference stations (not shown) are located in the vicinity of Mercator and Kidd mud volcanoes. Bathymetry from Zitellini et al. (2009).

The shallowest sites, Mercator $(350 \mathrm{~m})$ and Kidd MVs $(490 \mathrm{~m})$, belong to the El Arraiche field at the upper slope of the Moroccan margin (Van Rensbergen et al., 2005). Mercator MV is one of the two sites in the Gulf of Cadiz where active gas bubbling has been observed (the other one being Darwin MV; Vanreusel et al., 2009); the porewater is characterized by an extreme enrichment of $\mathrm{Cl}^{-}$and $\mathrm{SO}_{4}$ consistent with the dissolution of minerals (e.g. halite and gypsum), and $\mathrm{Li}$ concentration; radiogenic ${ }^{87} \mathrm{Sr} /{ }^{86} \mathrm{Sr}$ ratios are consistent with a terrigenous/continental deep source of the fluids (Scholz et al., 2010). The carbon isotopic signature of methane $\left(\delta^{13} \mathrm{C}:-33.8\right.$ to $-38.8 \%$ ) indicates high thermal maturity (Stadnitskaia et al., 2006; Hensen et al., 2007; Nuzzo et al., 2009). According to the scheme of dominant gas production and transport processes proposed by Nuzzo et al. (2009), Mercator MV is an example of admixture of thermogenic gases from different depths and influence of evaporate deposits. Meknès MV is located in the Moroccan carbonate province $(700 \mathrm{~m})$. The porewater is characterized by a moderate depletion of $\mathrm{Cl}^{-}$(Hensen et al., 2007; Scholz et al., 2010). The carbon isotopic signature of methane is more depleted $\left(\delta^{13} \mathrm{C}\right.$ : -48.9 to $-52.8 \%$ ) than in Mercator MV suggesting lower thermal maturity (Nuzzo et al., 2009).

Captain Arutyunov MV is located at ca. $1300 \mathrm{~m}$ water depth (just below the influence of the Mediterranean Outflow Water) and lies on one of the major SWIM (SW Iberian margin) lineaments, where the thickness of the accretionary prism is greatest (14 km; Thiebot and Gutscher, 2006). Both the thickness of the sediments and the low thermal gradient are thought to promote the production of large amounts of oil and hydrocarbon gases (Nuzzo et al., 2009 and references therein). The geochemistry is highly variable showing moderate $\mathrm{Cl}^{-}$enrichment, and often extremely steep porewater gradients and high turnover rates coinciding with a shallow sulfate-methane transition zone (Niemann et al., 2006; Hensen et al., 2007; Sommer et al., 2009; Scholz et al., 2010). The Capt. Arutyunov MV is categorized as an example of extensive generation and transport of fluids, petroleum and hydrocarbon gases from deeply buried sediments (Nuzzo et al., 2009).

The thickness of the accretionary prism decreases westwards where Carlos Ribeiro (ca. $2200 \mathrm{~m}$ ) and Bonjardim (ca. $3000 \mathrm{~m}$ ) are also aligned with major thrust faults. The geochemistry of these two mud volcanoes is very similar, and displays the advection of strongly hydrocarbon-enriched fluids (Nuzzo et al., 2009; Vanneste et al., 2011). The carbon isotopic signature of methane $\left(\delta^{13} \mathrm{C}\right.$ : -51.9 to $-69 \%$ o in Carlos Ribeiro and -49.4 to $-52.7 \%$ in Bonjardim) indicates low thermal maturity (Stadnitskaia et al., 2006; Nuzzo et al., 2009). The fluids show a distinctly depleted chlorinity that results from clay mineral dehydration promoted by positive heat flux anomalies (Nuzzo et al., 2009 and references therein; Scholz et al., 2010). Carlos Ribeiro and Bonjardim MVs are categorized as examples of active generation of $\mathrm{C}_{2+}$-enriched gases under tectonic control (Nuzzo et al., 2009).

Porto MV is located at the rim of the accretionary prism at ca. $3900 \mathrm{~m}$; the values ${ }^{87} \mathrm{Sr} /{ }^{86} \mathrm{Sr}$ are the least radiogenic and may be attributed to admixing of a basement-derived fluid component carrying an isotopic signature from interaction 
with the basaltic (oceanic) crust (Scholz et al., 2009, 2010). A relevant characteristic distinguishing Porto from the other deep mud volcanoes is that the isotope signatures suggest partial recycling of thermogenic methane mediated by AOMrelated methanogenic Archaea in the shallow sediments; subsequently Nuzzo et al. (2009) indicate Porto MV as a possible example of deep acetoclastic methanogenesis.

\subsection{Collection and processing of samples}

In most cold seep studies different habitats, such as tubeworm fields, mussel beds and bacterial mats, are identified and sampled discretely. In the Gulf of Cadiz the chemosymbiotic species are usually inconspicuous or burrowed, and in most cases it is practically impossible to use visual cues for targeted sampling. Herein we present data from samples collected in locations chosen following video surveys of the study sites, but using non-TV-assisted gear. Whenever applicable, observations regarding the dominant biological facies of each sample are given in Table 1. During the cruise TTR (Training-through-Research) 14 the macrofaunal assemblages in Kidd MV were sampled at the crater and at the flank; an additional sample was taken at some distance away of the mud volcano for reference. The same procedure was carried out at Mercator MV during the cruise TTR15. During the cruise MSM01-03, six mud volcanoes were sampled totalling 10 individual samples that were taken mostly from the crater area (Fig. 1, Table 1). In all cases a USNEL box corer (area $=0.25 \mathrm{~m}^{2}$ ) was used and the sample processing was initiated onboard by sub-sampling the different depth layers of the sediment. The material was sliced at $0-1,1-3,3-5,5-$ 10 , and $10-20 \mathrm{~cm}$ following the standard techniques adopted as general practice in HERMES and HERMIONE cruises. The supernatant water on box cores was passed through a $500 \mu \mathrm{m}$ sieve to retain any small fauna resuspended during sampling and core retrieval on deck. The sediment layers were carefully washed with seawater through $2 \mathrm{~mm}, 1 \mathrm{~mm}$ and $500 \mu \mathrm{m}$ sieves. The sieved material was fixed immediately in $96 \%$ ethanol. In the lab, the material was sorted under a stereo microscope into major taxa and kept in $96 \%$ ethanol, for taxonomic identification to species level whenever possible. Many taxa have not yet been matched with a species name but they were all sorted into putative species and ascribed a codename consistent throughout the samples. Therefore the estimated species richness can be considered accurate, although minor changes may be made in the future following more thorough taxonomic revisions of the material. Species abundances were determined for each sediment layer in each sample, but for the purposes of this paper sediment layer values were not used and densities were calculated as the number of individuals in relation to the area sampled and expressed as individuals per $\mathrm{m}^{2}$ (ind. $\mathrm{m}^{-2}$ ). Special attention was given to the count of Siboglinidae tubeworms (since the tube of many of them is brittle and the number of tube fragments generally does not correspond to the num- ber of animals). All tube fragments were dissected, and only those containing the forepart of the animal were considered.

\subsection{Data analysis}

Species richness, Shannon-Wiener diversity index $\left(H^{\prime}\right)$, Pielou (1969) evenness index $\left(J^{\prime}\right)$ and Hurlbert (1971) expected species richness $\left(\mathrm{ES}_{(n)}\right)$ were calculated using the community analysis PRIMER v6 software (Clarke and Gorley, 2006). This software was also used for multivariate analyses. The abundance data were first organized into a sample vs. species matrix, and non-metric multidimensional scaling (nMDS) ordination was performed using the Bray-Curtis similarity measure, after square root transformation. An analysis of similarities by randomization/permutation tests (ANOSIM) was performed on the MDS results of samples to assess for differences in the assemblages putatively related to the bathymetric variation in environmental conditions. Based on the characteristics of the study area mentioned above, the $1200 \mathrm{~m}$ water depth was used as the transition between two very different sets of oceanographic and geochemical conditions, and therefore the samples were grouped into the following three categories: R - Reference sites in the vicinity of Mercator and Kidd; SMVs - Shallow MVs including Mercator, Kidd and Meknès; DMVs - Deep MVs including Captain Arutyunov, Carlos Ribeiro, Bonjardim and Porto. The lack of replication did not allow for testing differences between individual MVs. SIMPER analysis (Similarity Percentages species contributions) was performed to assess the percentage contributions of each species to the similarity within and dissimilarity between groups of samples.

For the analysis of $\beta$-diversity, we used a dissimilarity matrix based on Bray-Curtis measure after square-root transformation. In order to describe different contributions for the overall $\beta$-diversity, the pairwise comparison values (PWCs) were grouped into seven categories: (i) WSMV - PWCs between samples within the same MV in the shallow field; (ii) BSMV - PWCs between samples from different MVs in the shallow field; (iii) WDMV - PWCs between samples within the same MV in the deep field; (iv) BDMV - PWCs between samples from different MVs in the deep field; (v) BS\&DMV - PWCs between Shallow and Deep MVs; (vi) BR\&SMV - PWCs between Reference sites and Shallow MVs; and (vii) BR\&DMV - PWCs between Reference sites and Deep MVs.

Diversity partitioning was assessed for species richness $(S)$, Hurlbert's expected number of species $\left(\mathrm{ES}_{(100)}\right)$ and Shannon-Wiener index $\left(H^{\prime}\right)$. The total diversity $(\gamma=\alpha+\beta)$ is partitioned into the average diversity within samples $(\alpha)$ and among samples $(\beta)$, and therefore $\beta$-diversity can be estimated by $\beta=\gamma-\alpha$ (Wagner et al., 2000; Magurran, 2004). To extend the partition across multiple scales $\left(\beta_{1}\right.$ : within $\mathrm{MV} ; \beta_{2}$ : between MVs; and $\beta_{3}$ : between MV fields), the smallest sample unit for level 1 are individual box core samples, while for the upper levels sampling units are formed 
Table 1. Metadata for the sampling stations in the Gulf of Cadiz. Station code: the label is composed of the cruise name and station number as used in Pangaea database (www.pangaea.de ); for simplification in figures and text the stations are referred to only by the three last digits.

\begin{tabular}{|c|c|c|c|c|c|c|}
\hline Location & Station code & Date & Lat. $(\mathrm{N})$ & Long. (W) & Depth (m) & Observations \\
\hline Reference & TTR15_AT577 & $26 \mathrm{Jul} 2005$ & $35^{\circ} 17.305^{\prime}$ & $06^{\circ} 39.672^{\prime}$ & 485 & Hemipelagic sediments \\
\hline Reference & TTR14_AT559 & 8 Aug 2004 & $35^{\circ} 24.777^{\prime}$ & $06^{\circ} 43.782^{\prime}$ & 552 & Hemipelagic sediments \\
\hline Mercator MV & TTR15_AT575 & $26 \mathrm{Jul} 2005$ & $35^{\circ} 17.905^{\prime}$ & $06^{\circ} 38.715^{\prime}$ & 355 & Crater, mud breccia \\
\hline Mercator MV & TTR15_AT576 & $26 \mathrm{Jul} 2005$ & $35^{\circ} 17.657^{\prime}$ & $06^{\circ} 39.129^{\prime}$ & 428 & Flank \\
\hline Mercator MV & MSM1/3_241 & 6 May 2006 & $35^{\circ} 17.918^{\prime}$ & $06^{\circ} 38.687^{\prime}$ & 353 & Crater, mud breccia, Caryophyllia facies \\
\hline Mercator MV & MSM1/3_242 & 6 May 2006 & $35^{\circ} 17.870^{\prime}$ & $06^{\circ} 38.717^{\prime}$ & 353 & Crater, mud breccia, Hyalinoecia facies \\
\hline Kidd MV & TTR14_AT560 & 8 Aug 2004 & $35^{\circ} 25.306^{\prime}$ & $06^{\circ} 43.976^{\prime}$ & 498 & Crater, mud breccia \\
\hline Kidd MV & TTR14_AT561 & 8 Aug 2004 & $35^{\circ} 25.602^{\prime}$ & $06^{\circ} 44.099^{\prime}$ & 526 & Flank \\
\hline Meknès MV & MSM1/3_319 & 14 May 2006 & $34^{\circ} 59.100^{\prime}$ & $07^{\circ} 04.439^{\prime}$ & 695 & Crater, stiff mud breccia \\
\hline Meknès MV & MSM1/3_321 & 14 May 2006 & $34^{\circ} 58.796^{\prime}$ & $07^{\circ} 04.394^{\prime \prime}$ & 732 & Seep periphery, carbonate and coral rubble \\
\hline Meknès MV & MSM1/3_335 & 15 May 2006 & $34^{\circ} 59.035^{\prime}$ & $07^{\circ} 04.552^{\prime}$ & 703 & Crater rim, coral rubble \\
\hline Capt. Arutyunov MV & MSM1/3_180 & 27 Apr 2006 & $35^{\circ} 39.740^{\prime}$ & $07^{\circ} 19.960^{\prime}$ & 1323 & Crater rim, buccinid facies \\
\hline Capt. Arutyunov MV & MSM1/3_218 & 30 Apr 2006 & $35^{\circ} 39.700^{\prime}$ & $07^{\circ} 20.012^{\prime}$ & 1318 & Crater, mud breccia with gas hydrates \\
\hline Carlos Ribeiro MV & MSM1/3_157 & 23 Apr 2006 & $35^{\circ} 47.270^{\prime}$ & $08^{\circ} 25.360^{\prime}$ & 2200 & Crater, mud breccia \\
\hline Bonjardim MV & MSM1/3_133 & 19 Apr 2006 & $35^{\circ} 27.821^{\prime}$ & $09^{\circ} 00.128^{\prime}$ & 3049 & Crater, mud breccia, shell ash and frenulate tubes \\
\hline Porto MV & MSM1/3_145 & 21 Apr 2006 & $35^{\circ} 33.699^{\prime}$ & $09^{\circ} 30.437^{\prime}$ & 3860 & $\begin{array}{l}\text { Crater, mud breccia, Lamelisabellal } \\
\text { Spirobrachia fields }\end{array}$ \\
\hline
\end{tabular}

by pooling together the appropriate groups of nested samples. The diversity components are calculated as $\beta_{m}=\gamma-\alpha_{m}$ at the highest level and $\beta_{i}=\alpha_{i+1}-\alpha_{i}$ for each lower level. The additive partition of diversity is

$\gamma=a_{1}+\sum_{i=1}^{m} \beta_{i}$.

The total diversity can therefore be expressed as the percentage contributions of diversity in each hierarchical level (Crist et al., 2003). Partitioning was carried out ascribing the same weight for each sample as they all represent the same area sampled (alternatively samples can be weighted by abundance; see Crist et al., 2003). Values of $\alpha_{i}$ were therefore calculated as a weighted average (according to the number of samples pooled).

\section{Results}

A total of 7036 specimens were ascribed to 366 putative species from which $111(30.0 \%)$ were singletons. Annelida $(52.2 \%$ of total abundance; 136 species) and Arthropoda $(33.5 \%$; 152 species) were the most abundant and the most species-rich Phyla. Mollusca and Echinodermata, although common, showed much lower values of abundance and species richness $(8.4 \% ; 56$ species and $3.6 \%, 12$ species, respectively). These four groups were represented in all samples except station 218 in Cap. Arutyunov MV (containing shallow gas hydrates), where crustaceans and echinoderms were absent. Although present in some samples, sponges and cnidarians were not included in this study.

\subsection{Symbiont-hosting species}

The 16 samples studied yielded a total of 20 symbionthosting species belonging to the bivalve families Thyasiridae (Thyasira vulcolutre), Vesicomyidae (Isorropodon megadesmus; Isorropodon perplexum) and Solemyidae (Acharax gadirae; Solemya elarraichensis) and the polychaete family Siboglinidae (Lamelisabella denticulata; Spirobrachia tripeira; Siboglinum cf. poseidoni; and eight other Siboglinum species, and four species of Polybrachia ascribed according to Hilário et al., 2010). Seven chemosymbiotic species occurred in the Shallow MVs (0-2 species per sample) and 16 in the Deep MVs (up to five different species per sample; Fig. 2a). Additionally the mixotroph bivalves Axinulus croulinensis and Thyasira granulosa were also present in the Shallow MVs, but because they are facultative heterotrophs they are included in the section below. Details on the distribution of chemosymbiotic species are given by Oliver et al. (2011) and Rodrigues et al. (2013). The abundance of chemosymbiotic species was highly variable (Fig. 3a) but, on average, lower in the Shallow MVs than in the Deep MVs (average $\pm \mathrm{SE}$; Siboglinidae: $221.3 \pm 112.1$ and $1578.4 \pm 939.0$ ind. $\mathrm{m}^{-2}$; bivalves: $1.3 \pm 1.3$ and $135.2 \pm 127.2$ ind. $\mathrm{m}^{-2}$, respectively). Chemosymbiotic species were often the dominant taxa in the Deep MVs, accounting for up to $79.5 \%$ of the total abundance. The highest number of individuals occurred in the two samples taken at Cap. Arutyunov MV: station 218 with the highest abundance of bivalves and the second highest abundance of siboglinids (161 and 567 ind. per $0.25 \mathrm{~m}^{2}$ ) and station 180 with the highest abundance of siboglinids (1240 ind. per $0.25 \mathrm{~m}^{2}$ ). A humbler maximal siboglinid count in the shallow field was recorded at station 242 at Mercator MV (261 ind. per $0.25 \mathrm{~m}^{2}$ ). Note that siboglinid counts refer 


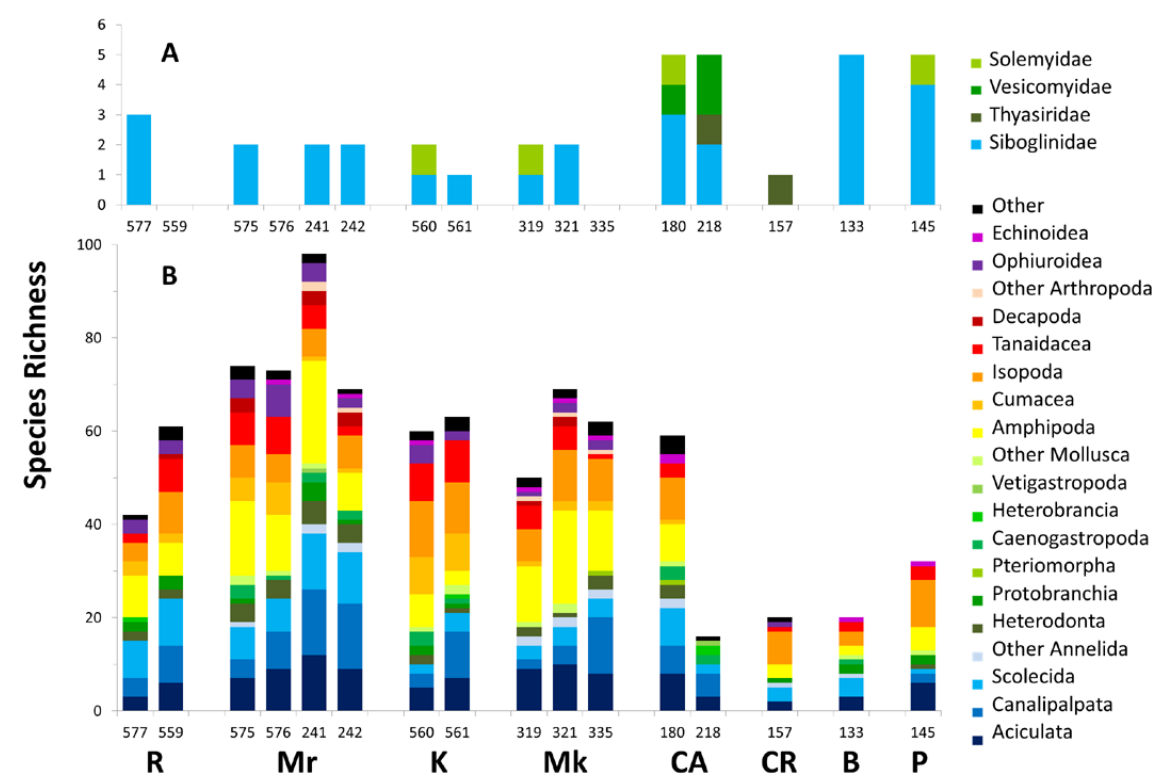

Fig. 2. Species richness per box core sample $\left(0.25 \mathrm{~m}^{2}\right)$. (A) Chemosymbiotic species (mixotrophic excluded) and (B) heterotrophic species. R: Reference sites; Mr: Mercator MV; K: Kidd MV; Mk: Menès MV; CA: Captain Arutyunov MV; CR: Carlos Ribeiro MV; B: Bonjardim MV; P: Porto MV. Numbers are the three last digits of the station code (Table 1).

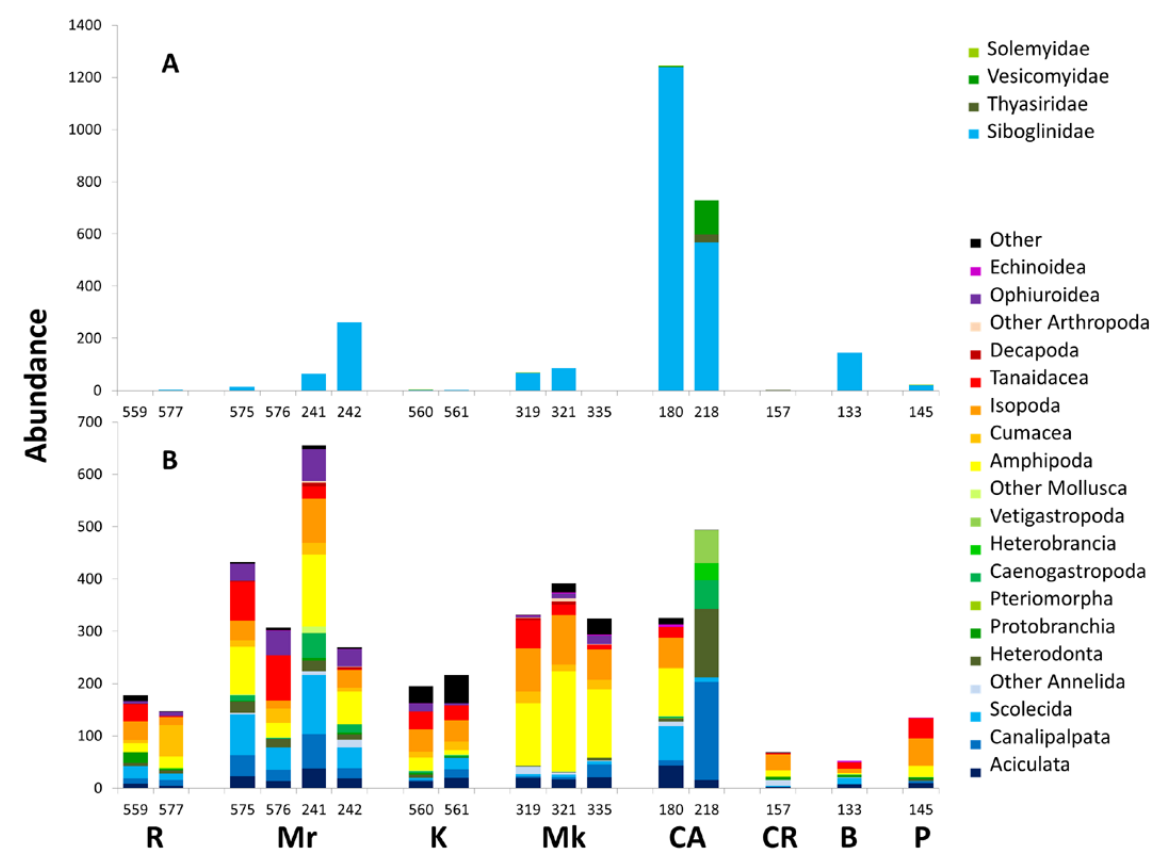

Fig. 3. Abundance per box core sample $\left(0.25 \mathrm{~m}^{2}\right)$. (A) Chemosymbiotic species (mixotrophic excluded) and (B) heterotrophic species. R: Reference sites; Mr: Mercator MV; K: Kidd MV; Mk: Menès MV; CA: Captain Arutyunov MV; CR: Carlos Ribeiro MV; B: Bonjardim MV; P: Porto MV. Numbers are the three last digits of the station code (Table 1).

only to occupied tubes and animals found out of the tubes; empty tubes can easily reach densities one order of magnitude higher.

\subsection{Heterotrophic species}

As for the remaining fauna, and in comparison with the two Reference sites $(51.5 \pm 9.5$ species per sample and $660 \pm 60.0$ ind. $\mathrm{m}^{-2}$ ), the Shallow MVs showed increased 
Table 2. Abundance and biodiversity data for macrofaunal samples. $n$ : number of deployments pooled; $A$ : area sampled; $N$ : number of individuals; $D$ : density; SE: standard error; $S$ : species richness; $\mathrm{ES}_{(100)}$ : Hulbert's expected number of species per 100 individuals; $H^{\prime}:$ ShannonWiener diversity (ln base); $J^{\prime}$ : Pielou's evenness; $k_{1}$ : percentage contribution of the first dominant species; R: Reference sites; Mr: Mercator MV; K: Kidd MV; Mk: Menès MV; CA: Captain Arutyunov MV; CR: Carlos Ribeiro MV; B: Bonjardim MV; P: Porto MV. SMV: Shallow MV samples pooled; DMV: Deep MV samples pooled; All: all samples pooled. Pooled values of $S$, ES $(100)$ and $H^{\prime}$ were used for diversity partition estimates; und.: undetermined species.

\begin{tabular}{|c|c|c|c|c|c|c|c|c|c|c|c|}
\hline Site & & $n$ & $\begin{array}{c}A \\
\left(\mathrm{~m}^{2}\right)\end{array}$ & $N$ & $\begin{array}{c}D \pm \mathrm{SE} \\
\left(\text { ind. } \mathrm{m}^{-2} \text { ) }\right.\end{array}$ & $S$ & $\mathrm{ES}_{(100)}$ & $\begin{array}{c}H^{\prime} \\
(\ln )\end{array}$ & $J^{\prime}$ & $\begin{array}{c}k_{1} \\
(\%)\end{array}$ & Dominant species \\
\hline $\mathrm{R}$ & 577 & & 0.25 & 152 & & 45 & 36.0 & 3.02 & 0.794 & 29.6 & Diastylidae sp003 \\
\hline $\mathrm{R}$ & 559 & & 0.25 & 178 & & 61 & 45.5 & 3.71 & 0.901 & 9.6 & Microgloma tumida \\
\hline $\mathbf{R}$ & & 2 & 0.50 & & $660 \pm 52.0$ & 93 & 50.5 & 3.96 & & & \\
\hline $\mathrm{Mr}$ & 575 & & 0.25 & 448 & & 76 & 37.5 & 3.45 & 0.796 & 15.0 & Paradoneis lyra \\
\hline $\mathrm{Mr}$ & 576 & & 0.25 & 307 & & 73 & 41.2 & 3.63 & 0.847 & 12.7 & Fageapseudes retusifrons \\
\hline $\mathrm{Mr}$ & 241 & & 0.25 & 720 & & 100 & 45.0 & 3.94 & 0.856 & 7.5 & Paradoneis lyra \\
\hline $\mathrm{Mr}$ & 242 & & 0.25 & 529 & & 71 & 31.5 & 2.92 & 0.685 & 28.9 & Siboglinum spIb \\
\hline Mr & & 4 & 1.00 & & & 188 & 48.2 & 4.14 & & & \\
\hline $\mathrm{K}$ & 560 & & 0.25 & 200 & & 62 & 43.6 & 3.64 & 0.881 & 10.5 & Atlantapseudes nigrichella \\
\hline $\mathrm{K}$ & 561 & & 0.25 & 217 & & 64 & 42.8 & 3.63 & 0.873 & 11.5 & Sipuncula sp002 \\
\hline $\mathrm{K}$ & & 2 & $\mathbf{0 . 5 0}$ & & & 97 & 48.1 & 3.96 & & & \\
\hline $\mathrm{Mk}$ & 319 & & 0.25 & 400 & & 51 & 28.3 & 2.98 & 0.758 & 20.0 & Harpinia sp020 \\
\hline $\mathrm{Mk}$ & 321 & & 0.25 & 478 & & 71 & 36.8 & 3.49 & 0.819 & 13.6 & Siboglinum spIf \\
\hline Mk & 335 & & 0.25 & 324 & & 62 & 37.2 & 3,49 & 0.845 & 10.5 & Lembos sp037 \\
\hline Mk & & 3 & 0.75 & & & 115 & 40.7 & 3.78 & & & \\
\hline SMV & & 9 & 2.25 & & $1610 \pm 218.7$ & 280 & 56.6 & 4.58 & & & \\
\hline $\mathrm{CA}$ & 180 & & 0.25 & 1567 & & 64 & 14.9 & 1.41 & 0.340 & 72.5 & Siboglinum spId \\
\hline $\mathrm{CA}$ & 218 & & 0.25 & 1091 & & 21 & 10.5 & 1.65 & 0.541 & 51.4 & Siboglinum cf. poseidoni \\
\hline $\mathbf{C A}$ & & 2 & 0.50 & & & 76 & 17.3 & 2.05 & & & \\
\hline $\mathbf{C R}$ & 157 & & 0.25 & 70 & & 21 & - & 2.59 & 0.852 & 18.6 & Desmosomatidae und. \\
\hline $\mathrm{B}$ & 133 & & 0.25 & 198 & & 25 & 18.0 & 1.98 & 0.615 & 46.0 & Siboglinum spIc \\
\hline $\mathbf{P}$ & 145 & & 0.25 & 157 & & 37 & 30.5 & 3.06 & 0.847 & 15.9 & Desmosomatidae und. \\
\hline DMV & & 5 & 1.25 & & $2466 \pm 1204.5$ & 124 & 24.9 & 2.58 & & & \\
\hline All & & 16 & 4.00 & 7036 & & 366 & 51.6 & 4.25 & & & \\
\hline
\end{tabular}

species richness and abundance $(68.7 \pm 4.4$ species per sample and $1387.6 \pm 860.0$ ind. $\mathrm{m}^{-2}$ ) while the Deep MVs showed decreased species richness and only slightly higher abundance $(29.4 \pm 7.9$ species per sample and $860.6 \pm 339.7$ ind. $\mathrm{m}^{-2}$ ) than the Reference sites. The highest number of species and individuals of heterotrophic species was found at station 241, an area with solitary corals (Caryophyllia sp.) at Mercator MV (98 species and 665 ind. per $0.25 \mathrm{~m}^{2}$ ), the lowest species richness at station 218 in association with dissociating gas hydrates at Capt. Arutyunov MV (16 species), and the lowest abundance at station 133, an area covered by shell ash at Bonjardim MV (52 ind. per $0.25 \mathrm{~m}^{2}$ ) (Figs. $2 \mathrm{~b}$ and $3 b)$.

The composition of the mud volcano assemblages at the level of major taxonomic groups (chemosymbiotic species excluded) does not reveal clear trends in relation to the Reference sites. In terms of abundance (Fig. 3b), the relative contribution of polychaetes is increased in Mercator, Cap. Arutyunov and Bonjardim MVs, and decreased in Meknès and Porto MVs; overall, crustaceans dominate most mud volcano assemblages except for station 218 at Cap. Arutyunov
MV $(0 \%)$, and are particularly abundant in Meknès (in average the amphipods account for over $40 \%$ of the abundance), Carlos Ribeiro (isopods: $45 \%$ ) and Porto MVs (isopods: $39 \%$ ); the contribution of molluscs is decreased in Kidd and Meknès MVs and greatly increased in Capt. Arutyunov MV; finally, the abundances of ophiuroids in Mercator MV and sipunculids in Kidd MV are also relevant $(8.7 \%$ and $20.4 \%$, respectively).

In terms of species richness (Fig. 2b), the relative contribution of Scolecida (Polychaeta) is often impoverished in the mud volcano assemblages (e.g. Meknès, Carlos Ribeiro, Bonjardim, Porto MVs) while the opposite occurs with the gastropods (Mercator, Kidd, Capt. Arutyunov MVs) and crustaceans (Kidd, Meknès, Carlos Ribeiro and Porto MVs); decapods (e.g. the small crabs Cymonomus granulatus, Ebalia nux, and Monodaeus couchii) were found exclusively in Mercator and Meknès MVs ( 7 and 2 species, respectively). 


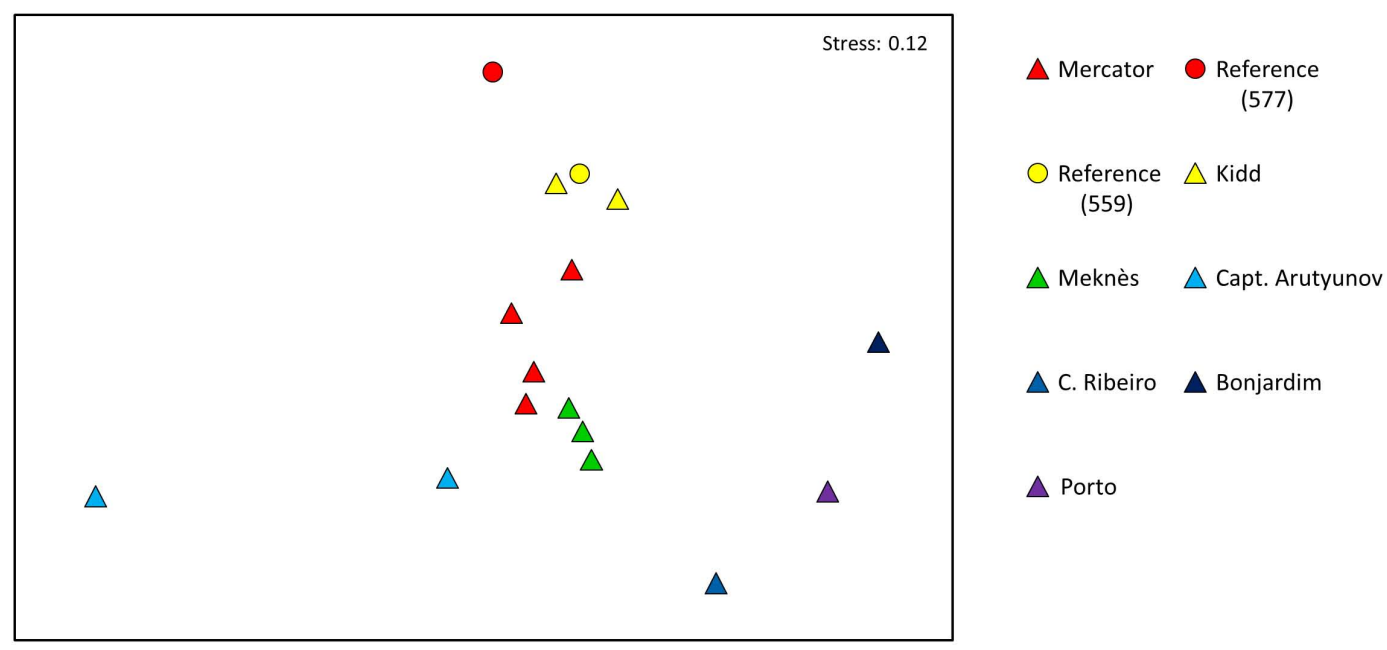

Fig. 4. MDS plots for the comparison between samples from Reference sites, Shallow MVs (Mercator, Kidd and Meknès) and Deep MVs (Capt. Arutyunov; Carlos Ribeiro, Bonjardim and Porto).

\subsection{Comparison between Shallow and Deep MVs}

The MDS plot (Fig. 4) based on the whole data set (chemosymbiotic and heterotrophic species) reflects well the variability in the composition of the assemblages. It shows a high dispersion of the heterogeneous Deep MV samples (along the first axis in Fig. 4), and the Shallow MV samples closer together and clustering per mud volcano, but spreading (along the second axis in Fig. 4) in between the Reference sites and the Deep MVs. The results of the ANOSIM test support a significant overall difference between sites (global R: $0.618 ; 0.1 \%$ significance level) as well as for the pairwise comparisons between Shallow MVs and Reference sites (R: 0.517; significance level: $3.6 \%$; all 55 possible permutations used) and between Shallow and Deep MVs (0.674; $0.2 \% 999$ permutations). The comparison between Deep MVs and Reference sites retrieved a non-significant value $(0.400 ; 14.3 \%)$ owing to the high heterogeneity of Deep MV samples combined with the low number of possible permutations (21).

In common, the assemblages from the Shallow MVs have higher biodiversity and evenness $\left(H^{\prime}: 2.92-3.94\right.$; $\left.\mathrm{ES}_{(100)}: 28.3-45.0 ; \quad J^{\prime}: 0.685-0.881 ; k_{5}: 28.2-60.5 \%\right)$ whereas the assemblages from the Deep MVs showed, in general, contrasting characteristics but were more heterogeneous $\left(H^{\prime}: 1.41-3.06 ; \mathrm{ES}_{(100)}: 10.5-30.5 ; J^{\prime}: 0.340-0.852\right.$; $k_{5}$ : 49.7-89.7\%; Table 2); the assemblage from the siboglinid fields in Porto MV, with the highest evenness and biodiversity among the Deep MVs, was particularly distinct.

The polychaetes Paradoneis lyra and Lauberiopsis cabiochi, the tanaids Fageapseudes retusifrons and Atlantapseudes nigrichela, and the ophiuroids Amphiura filiformis and Amphipholis squamata were frequently found among the dominant species in the Shallow MVs while the Deep MVs were often dominated by different chemosymbiotic species. The dominant species are generally retrieved by the SIMPER analysis as the major contributors for the similarity and dissimilarity of the groups of samples (Supplementary material). The major contributors for the average similarity of the Reference sites are deposit and suspension feeders such as Scolecida polychaetes (Aricidea simonae, Capitellidae sp005, Ophelina cf. cylindricaudata, Paradoneis lyra), the bivalve Microgloma tumidula and the ophiuroid A. squamata as well as several crustaceans (Ampelisca sp022, Leucon sp001, Sphyrapus malleolus). In the Shallow MVs major contributors are again deposit feeders but also include carnivore/omnivore polychaetes (e.g. Glycera lapidum, Paradiopatra hispanica), and detritivore crustaceans, several with a more opportunistic diet (e.g. caprellid amphipods, apseudomorph tanaids). In the Deep MVs the detritivore contributors are mostly asellote isopods and tanaidomorph tanaids; the polychaete contributors are mostly Aciculata species (carnivores/omnivores) and siboglinids (chemosymbiotic). The siboglinids are also major contributors for the Shallow/Deep and Reference/Deep average dissimilarities. The Reference/Shallow average dissimilarity is explained mostly by crustaceans (mainly amphipods). Overall, SIMPER results are determined by the high variability in the composition of the assemblages. The average similarities for the three groups Reference, Shallow and Deep are very low $(20.1,27.6$ and $12.8 \%$, respectively) because there are many singletons and few common species among samples. For the same reason, the average dissimilarities for the comparisons between groups are very high (R/S: $81.4 \%$; R/D: $92.8 \%$; S/D: 87.8 ) and are accounted for by a large number of species with very low percentage contributions.

\subsection{Biodiversity analyses}

The rarefaction curves (Fig. 5) all show relatively steep slopes (partly explained by the large number of singletons) 


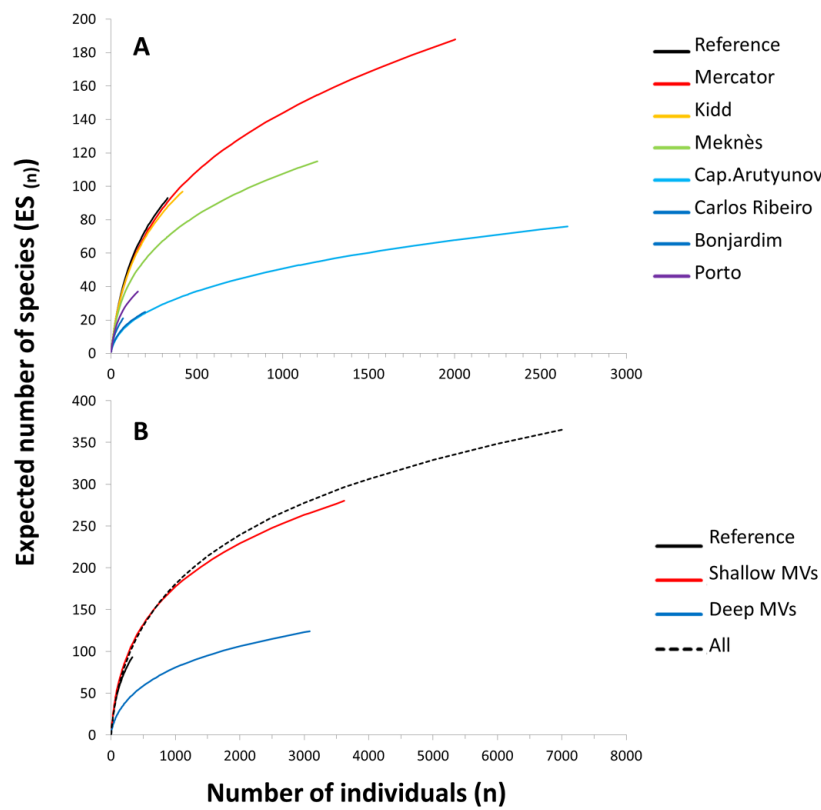

Fig. 5. Comparison of rarefaction curves (Hurlbert's expected number of species) for the assemblages pooled by mud volcano (A) and pooled by sub-region (B).

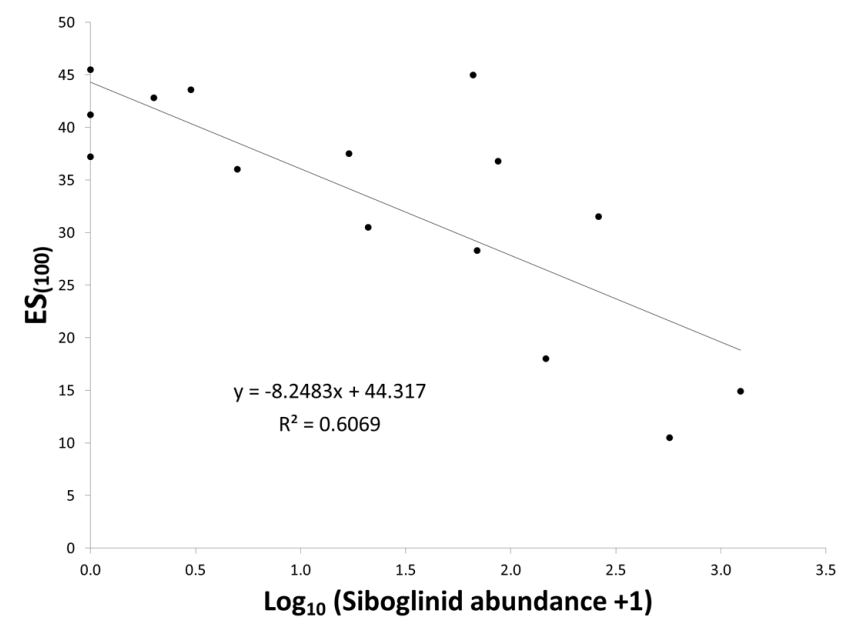

Fig. 6. Relationship between the rarefied biodiversity (Hurlbert's expected number of species $\left.\mathrm{ES}_{(100)}\right)$ and siboglinid abundance in each individual sample $(n=15)$.

and are far from reaching asymptotic values revealing that the sampling effort is insufficient to assess the full biodiversity either at individual MVs or at larger scales. These curves also demonstrate the contrasting biodiversity of the deep and Shallow MVs as well as the convergence of the latter with the Reference sites, both at the scale of the individual MVs (Fig. 5a) and at the regional scale (Fig. 5b). At the small scale (individual sample; $\alpha$-diversity) siboglinid abundance explains about $60 \%$ of the variability in $\mathrm{ES}_{(100)}$ values. Figure 6 shows that there is a significant negative relation-

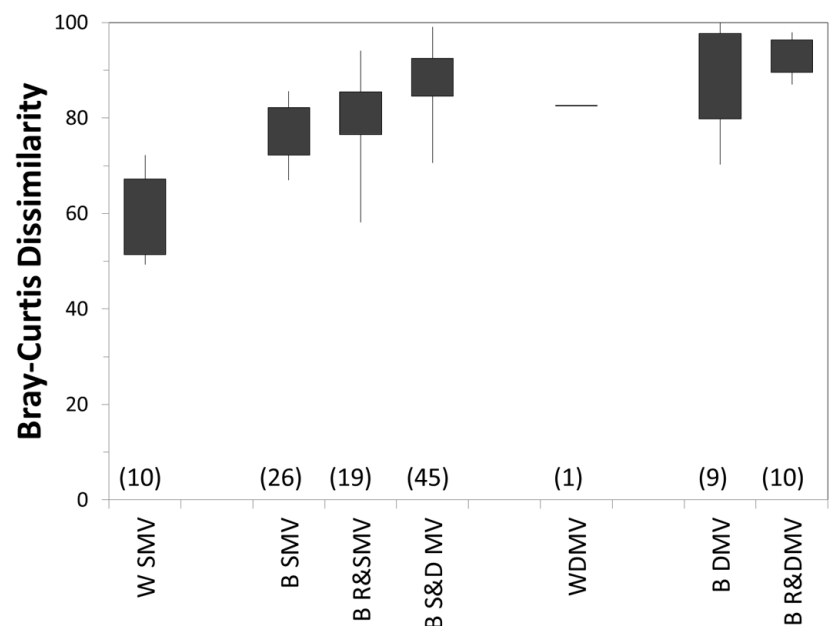

Fig. 7. $\beta$-diversity analysis based on Bray-Curtis dissimilarity between all possible pairs of individual samples. Bars show the range (line) and 25-75 percentile (box) of pairwise comparisons in each category (number of pairwise comparisons in brackets). W SMV: within Shallow MVs; B SMV: between Shallow MVs; BR\&SMV: between Reference sites and Shallow MVs; BS\&DMV: between Shallow and Deep MVs; W DMV: within Deep MVs; B DMV: between Deep MVs; BR\&DMV: between Reference sites and Deep MVs.

ship between $\mathrm{ES}_{(100)}$ and siboglinid abundance $(\log 10(n+1)$, $R^{2}$ : 0.6069; regression coefficient $r: 0.779, p<0.001$ ).

The $\beta$-diversity analysis (Fig. 7) confirms the high variability of the faunal assemblages: the lowest dissimilarity obtained for the pairwise comparison between two samples of the Meknès MV was rather high (49.3\%). Complementarity increases progressively for pairwise comparisons involving Shallow MVs - from comparisons within the same MV to between Shallow and Deep MVs (WSMV $<$ BSMV $<$ BR\&SMV $<$ BS\&DMV). Comparisons involving Deep MVs showed very high dissimilarity values and widely overlapping ranges in the different categories (WDMV, BDMV, BS\&DMV, BR\&DMV). Station 218 at Capt. Arutyunov MV was particularly distinct - PWCs involving this station showed consistently the highest dissimilarity values $(95.5-100 \%$ between station 218 and stations from other mud volcanoes; $82.6 \%$ between station 218 and station 180 also in Capt. Arutyunov MV).

The partitioning of diversity (Fig. 8) shows that only $15.4 \%$ of the total species richness is due to $\alpha$-diversity (the average number of species per sample is 56.5 for a grand total of 366) and that most of the $\beta$-diversity is due to differences in species composition between MV fields $\left(\beta_{3}: 43.2 \%\right)$ and between individual MVs $\left(\beta_{2}: 27.6 \%\right)$ - this partition can be explained by the high number of singletons, low number of species shared by two or more MVs and high rate of species replacement along the depth gradient. When the Shannon-Wiener index is calculated (the abundance is taken into account), the dominant species have more weight in 


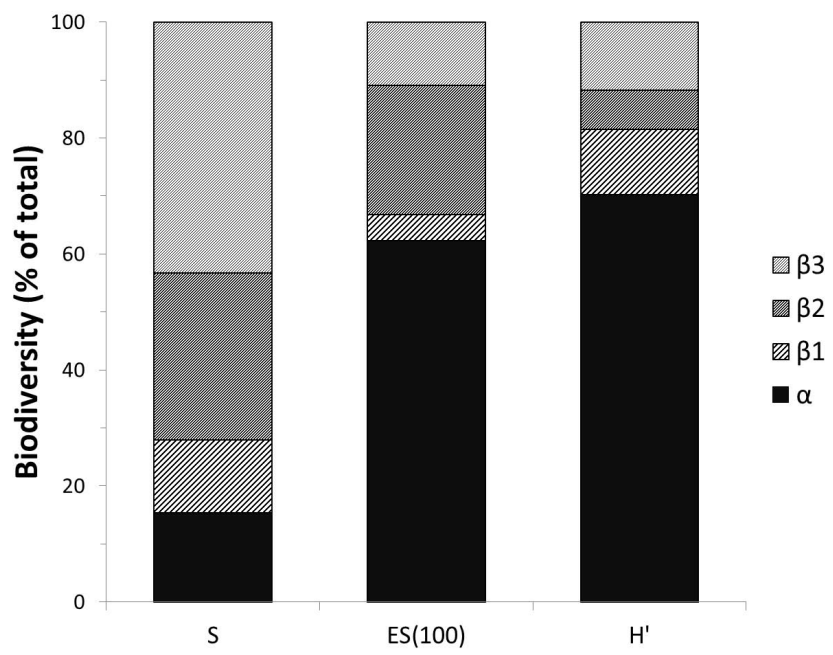

Fig. 8. Partition of diversity for different indices. $S$ : number of species; $\mathrm{ES}_{(100)}$ : Hurlbert expected number of species per 100 individuals; $H^{\prime}$ : Shannon-Wiener diversity (ln-based). $\beta_{1}$ : $\beta$-diversity within mud volcanoes; $\beta_{2}$ : $\beta$-diversity between mud volcanoes; $\beta_{3}: \beta$-diversity between sub-regions.

explaining the partition of diversity - in this case the few samples showing high dominance (e.g. station 180 and station 218 in Capt. Arutyunov) do not affect much the average sample $\alpha$-diversity $\left(2.99 ; 70.3 \%\right.$ of the total $H^{\prime}$ diversity), but they are sufficiently important to explain the relatively high contributions of $\beta_{1}$ and $\beta_{3}$ (11.2 and $11.7 \%$, respectively). These levels are the most impacted because the dominant species are not the same in the samples from the same MV (level $\beta_{1}$ ) and because of the disproportionate effect of the abundance (and dominance) of the Capt. Arutyunov samples in the estimates of $H^{\prime}$ for the Deep MV field. Rarefaction $\left(\mathrm{ES}_{(100)}\right.$ estimates) somehow balances the weights of singletons and dominant species showing a partition of diversity with still high but intermediate contribution of $\alpha$-diversity $(60.3 \%)$ and a major contribution of level 2 (between MVs; $\beta_{2}: 22.3 \%$ ) for $\beta$-diversity. Note that in the partition of diversity the expected contribution of $\alpha$-diversity is higher for $S$ than for $\mathrm{ES}_{(100)}$ or $H^{\prime}$ (Crist et al., 2003) the number of species is cumulative with increasing scales (always higher for larger scales) while in the case of $\mathrm{ES}_{(100)}$ or $H^{\prime}$ some individual samples can yield values that are close to or even higher than the estimates for pooled samples.

\section{Discussion}

\subsection{Faunal assemblages in the Gulf of Cadiz and other cold seeps}

The number of species reported here either globally (366 species) for the Gulf of Cadiz (GoC) or for each individual MV (21-76 species in the Deep MVs; 97-188 in the Shallow MVs) is certainly among the highest ever reported for cold seeps. There are very few cold seep studies with species-level taxonomic resolution to enable comparisons of species richness or other biodiversity indices $\left(H^{\prime}\right.$, $\mathrm{ES}_{(100)}$ ) between different regions, and the usual discrepancies in methodologies further complicate such comparisons. Levin et al. (2010) provide counts of up to 55 and 88 species from clam beds in Hydrate Ridge and Eel River (NE Pacific), respectively, at depths comparable to the Shallow MVs in GoC. Eleven locations at depths between 1005 and $2750 \mathrm{~m}$ in the Gulf of Mexico yielded a total of 88 taxa and $\mathrm{ES}_{(100)}$ values ranging 7.7-15.4 (Cordes et al., 2010a). Other reported ES $_{(100)}$ estimates for various cold seeps vary between 8 and 36 (Levin, 2005; Levin et al., 2010) or between 4.0 and 27.5 (Bernardino et al., 2012). The values observed in the Deep MVs of the GoC (10.5-30.5) are within this range, but the ones in the Shallow MVs were consistently higher (mostly over 36 and up to 45). Cold seep assemblages in general tend to be highly dominated by sulfide-tolerant species and therefore show low $\mathrm{ES}_{(100)}$. The values obtained from the Deep MVs assemblages are similar to the ones reported from hydrodynamically disturbed and/or organically enriched deepsea areas in the NE Atlantic such as the Nazaré canyon $\left(\mathrm{ES}_{(100)}\right.$ : 16.9-33.4; Cunha et al., 2011) or the summit of the Condor Seamount $\left(\mathrm{ES}_{(100)}\right.$ : 20.4; Bongiorni et al., 2013). The $\mathrm{ES}_{(100)}$ estimates from pooled samples in the groups reference, Shallow MVs and Deep MVs are similar (50.5), higher (56.6) and lower (24.9), respectively, than the mean value (50) obtained from different deep-sea regions (review by Snelgrove and Smith, 2002).

On the other hand, the average densities of the mud volcano assemblages (1610 and 2466 ind. $\mathrm{m}^{-2}$ for the Shallow and Deep MVs, respectively; mesh size: $500 \mu \mathrm{m}$ ) in the $\mathrm{GoC}$ are far from the reported maximal values for other cold seeps: 93000 ind. $\mathrm{m}^{-2}$ from Oligobrachia haakonmosbiensis fields in the Håkon Mosby MV (mesh size: $500 \mu \mathrm{m}$; Decker et al., 2012) and over 20000 ind. $\mathrm{m}^{-2}$ from Calyptogena beds in Hydrate Ridge (mesh size: $300 \mu \mathrm{m}$; Levin, 2005), mytilid beds in Regab (mesh size: $250 \mu \mathrm{m}$; Menot et al., 2010) and reduced sediments from Amsterdam MV in the eastern Mediterranean (mesh size: $250 \mu \mathrm{m}$; Ritt et al., 2012). However, they are in line with reported values from thyasirid beds in the North Sea (mesh size: $500 \mu \mathrm{m}$; Dando et al., 1991), Acharax beds at Hydrate Ridge (mesh size: $500 \mu \mathrm{m}$; Sahling et al., 2002) and several habitats from Napoli MV in the eastern Mediterranean (mesh size: $250 \mu \mathrm{m}$; Ritt et al., 2012).

High variability of abundances between different habitats has been reported in most of these and in other regions (Bernardino et al., 2012), but the comparisons between different studies and regions are often confounded by methodological aspects (e.g. sampling gear, mesh size and sorting technique), and by the different bathymetric and biogeographic settings of different study areas. Although there is apparently no clear relationship to the geochemistry of 
the fluids (Levin, 2005), the huge variability in the densities reported for cold seeps must result from the influence of symbiont-hosting foundation species and the availability of colonizers determined by depth and biogeography operating on the numerous combinations of geological drivers, fluid flux, and biogeochemical processes occurring in these ecosystems.

Methanotrophic symbiont-hosting species (e.g. Siboglinum poseidoni) may significantly modify sediment geochemistry by promoting sulfate reduction, which has a dual effect on the macrofaunal assemblages: by increasing sulfide porewater concentration while diversifying niches for microbial communities, they increase toxicity for the infauna but also diversify sources of food derived from microbial activity (Levin et al., 2003; Sommer et al., 2009). The predicted outcome is a macrofaunal assemblage highly dominated by sulfide-tolerant heterotrophic species (Levin and Mendoza, 2007) and/or thiotrophic species, which is in agreement with the high abundance and low evenness values observed in siboglinid-dominated assemblages from the GoC, and by the significant negative relationship between siboglinid abundance and small-scale $\alpha$-diversity. For instance, localized optimal conditions for the establishment of Siboglinum spp. fields (Sommer et al., 2009) lead to maximal densities and lowest evenness and $\mathrm{ES}_{(100)}$ occurring in Capt. Arutyunov MV. In Porto MV, the siboglinid fields are characterized by varying densities of the larger-sized species Lamelisabella denticulata and Spirobrachia tripeira. Their tubes protruding from the sediment, often as clumps, host a diverse epifauna, and the macrofaunal assemblage here showed high evenness and $\mathrm{ES}_{(100)}$ values. The morphology and physiology of frenulate tubeworms, capable of overcoming low fluid flow conditions (Sommer et al., 2009), enables them to form dense populations under a very wide range of geochemical conditions including warm, methane-rich, mantle-influenced seepage (Levin et al., 2012) and to endure high temporal and spatial variability. Apparently, they may also yield very different attendant macrofaunal assemblages.

In the deep sea, benthic macrofaunal assemblages are highly dependent on allochthonous organic matter (Rex et al., 2006; Smith et al., 2008). Chemosynthesis-derived organic matter and free-living chemolithotrophic bacteria and Archaea available at cold seeps constitute a relevant addition to the nutrition of heterotrophic organisms (Carney, 1994). As in many other locations (e.g. review by Levin, 2005; Levinet al., 2010; Menot et al. 2010; Bernardino et al., 2012), in the GoC we observed increased abundance at seeps in comparison to Reference sites at comparable depths. There were no reference samples for the deeper sites which yielded generally lower abundance than the Shallow MVs. Diversified food sources may explain the increased abundance (and biomass) in seeps relative to Reference sites and an increasing dependence on chemosynthetic food sources at deeper seeps as the availability of photosynthetically derived material decreases (Sahling et al., 2003; Levin and
Sibuet, 2012). This pattern is very clear in the GoC by the increasing prevalence of chemosymbiotic species in the assemblages of the Deep MVs both in terms on species richness and abundance and by the occurrence of mixotrophs exclusively in the Shallow MVs. Also interesting are the changes in the trophic structure of the attendant heterotrophic assemblages in cold seeps. In general, most deep-sea organisms are deposit feeders (Jumars and Wheatcroft, 1989), but we observed higher trophic diversity in the GoC mud volcano assemblages. The available bacterial biomass and dissolved or particulate organic matter favours increased contributions of grazers such as gastropods putatively feeding on free-living bacteria (e.g. in Mercator, Kidd and Capt. Arutyunov MVs). Other opportunistic feeders such as corophioid amphipods and apseudomorph tanaids (mostly in Shallow MVs) use their appendages to collect detritus from the sediment but also may use a secondary filter feeding strategy (Larsen, 2005). Because the high-density assemblages in the mud volcanoes may support higher trophic levels, omnivores and carnivores or scavengers such as Aciculata polychaetes (both in Shallow and Deep MVs) and small crabs (Shallow MVs) are also well represented by relatively common species (e.g. Glycera lapidum, Paradiopatra hispanica, Monodaeus couchi). Grazers and non-lethal predators are customary in many seeps (e.g. review by Sibuet and Olu, 1998; Olu-Le Roy et al., 2004), but the limited foraging options due to defensive and/or environmental toxicity in cold seeps and a relative lack of deep-sea candidates for evolutionary specialized predation make this option selectively disadvantageous (Carney, 1994).

\subsection{Depth-related variability in faunal assemblages}

Depth-related changes in the abundance, biodiversity and composition of cold seep assemblages are still poorly known (Levin and Sibuet, 2012). Besides the work by Sahling et al. (2003) in the Sea of Okhotsk covering a depth range from 160 to $1600 \mathrm{~m}$ and the work by Cordes et al. (2010a) in the Gulf of Mexico comparing the assemblages from 11 locations between 1005 and $2750 \mathrm{~m}$ with shallower sites, there are few studies attempting to infer depth-related effects on cold seep assemblages within the same region of a continental margin. Detailed accounts of seep macrofauna focus mainly on shelf or upper slope sediments, and there is little detailed information on the macrofauna of seeps deeper than $3000 \mathrm{~m}$ (Levin and Mendoza, 2007) also owing to the logistic difficulties (adequate equipment and working time restrictions) in accessing greater depths. With over 40 known mud volcanoes spanning shelf to abyssal depths, the Gulf of Cadiz provides an ideal setting for such studies. However, the lack of visual cues (conspicuous symbiont-hosting megafauna) for targeted sampling of different habitat types and the few opportunities for quantitative collections limited the options for replicate sampling and constrained our working hypothesis. Therefore, we focused our analysis on the 
differences between two groups of MVs, Shallow and Deep, separated by a transition depth of $1200 \mathrm{~m}$ coinciding with relevant changes in the oceanographic and geologic settings. Among the most striking environmental features are the following: (i) the influence of the Mediterranean Outflow Water impinging higher seawater temperatures and lower oxygen to the benthic assemblages of shallower MVs; (ii) the transition from continental-oceanic crust and thickness of the accretionary prism, which are determinant for the dominant fluid sources and transport mechanisms; (iii) the SWIM faults acting as main upward conduits for the fluids at the Deep MV field; and (iv) the occurrence of solid-phase methane hydrates at the Deep MVs.

The interpretation of the MDS plot suggests that some of the Shallow MV assemblages are more closely related to the Reference assemblages, and the dispersion of Shallow and Deep MV samples along the vertical and horizontal axis, respectively, indicates that the prevalent factors of change in each field may differ.

Shallow MVs show a milder seepage regime with low chemical toxicity (Hensen et al. 2007; Nuzzo et al., 2009; Scholz et al., 2009, 2010). The higher seawater temperatures and the proximity to the coast and to the euphotic zone add to a greater input of photosynthetically derived organic matter. These environmental conditions make the Shallow MVs highly permeable to the penetration of background fauna leading to high abundance and diversity of the attendant faunal assemblages. The occurrence of authigenic carbonates (Magalhães et al., 2012) and fossil cold water corals (Wienberg et al., 2009) increases habitat heterogeneity and diversifies the suite of potential habitats for invertebrates (Cordes et al., 2010b). The trophic diversity is also enhanced (as mentioned above), and the chemosymbiotic species are thiotrophic or mixotrophic showing modest abundance and species richness.

Deep MVs have a more intense fluid expulsion regime, more diversified substrates for chemolithotrophic metabolism and methane reservoirs (Hensen et al. 2007; Nuzzo et al., 2009; Scholz et al., 2009, 2010), which can more reliably sustain the persistence in time of AOM activity and chemosynthesis-dependent invertebrate assemblages. The assemblages are often dominated by elevated abundances of thiotrophic or methanotrophic species that also show a remarkable diversity (see also Rodrigues et al., 2013). There is a substantial variability in environmental conditions between MVs in the deep field (Hensen et al., 2007; Nuzzo et al., 2009; Scholz et al., 2009, 2010), and each individual MV possesses very distinct assemblages. In the GoC, the most active mud volcanoes are in the deep field. Worldwide, methane seeps are especially common and active at water depths of $500-1000 \mathrm{~m}$, where temperature and pressure combine to destabilize gas hydrates (Hester and Brewer, 2009), but in the GoC this depth may be greater owing to the influence of the warmer Mediterranean Outflow Water. Located just below the influence of this water mass, Capt. Arutyunov is one of the most active mud volcanoes in the GoC with methane dissolving from the layer of gas hydrates at local points of instability and seeping through the subsurface sediments at relatively high concentrations (Niemann et al., 2006; Sommer et al., 2009) - station 218, where gas hydrates were collected, shows a typical seep assemblage of siboglinids, vesicomids, microgastropods and ampharetid polychaetes. The two samples taken from Capt. Arutyunov also illustrate the high variability of the seep assemblages within the same MV at the deep field even though different habitat types cannot be recognised visually.

In the Gulf of Mexico (GoM) the general features of deepsea communities (e.g. mid-slope diversity maximum and high species turnover at $100 \mathrm{~m}$ depth) are extended to the specialized habitats of cold seeps, and there is a prevalence of depth over geographical distance as a factor of change (Cordes et al., 2010a). Although the influence of the oceanographic setting may act at large geographic scales upon both seep and non-seep habitats in the GoC, it may have habitatspecific effects on seep assemblages, which also do not seem to follow a predictable depth-related diversity trend. However other depth-related features in the $\mathrm{GoC}$ are shared with the GoM: a higher degree of novelty in the fauna, high variability in the composition and structure of the assemblages likely driven by habitat heterogeneity, and subsequent high $\beta$-diversity. In different regions, the main differences between seep assemblages have been consistently related more closely to habitat type and/or foundation symbiont-hosting species than to geographical distance or depth (Olu-Le Roy et al., 2004; Levin and Mendoza, 2007; Cordes et al., 2010a; Menot et al., 2010; Decker et al., 2012; Ritt et al., 2012), and most of the $\beta$-diversity has been allocated to habitat-related differences between the faunal assemblages. In the GoC, maybe because habitat types cannot be clearly discriminated, the dissimilarity is lowest for within Shallow MV comparisons and increases with increasing spatial scale. Again the Deep MVs show a different pattern with consistently high dissimilarities at all spatial scales. The partition of diversity also showed the relevance of $\beta$-diversity at the level of "between MV fields" ( $\beta_{3}$ level) for the three diversity indicators analysed. $\beta_{3}$ level represented even the highest contribution to $\beta$-diversity in the partition of species richness, which we attributed to the high rate of species replacement along the depth gradient.

\subsection{A hotspot of biodiversity}

The 366 species reported here for the GoC are only a fraction of the over 1000 taxa (unpublished data) estimated from quantitative and non-quantitative samples collected up to now in over 18 mud volcanoes and other locations in adjacent habitats (carbonate chimneys and concretions, dead scleractinian cold water corals). Comprehensive studies on species distributions of major taxa have been published or are in preparation (Rodrigues et al., 2011b; Génio et al., 2013). 
A significant effort has been allocated to taxonomic work for species-level identification including the description of new heterotrophic and chemosymbiotic species (Dworshack and Cunha, 2007; Błażewicz-Paszkowycz, 2011a, b; Hilário and Cunha, 2008, Oliver et al., 2011; Rodrigues et al. 2008, 2011b), and molecular approaches (e.g. Génio et al., 2008) leading to the discovery of a high diversity of taxa with low genetic divergence (e.g. Hilário et al., 2010; Moura et al., 2011,2012 ). In fact, the 22 chemosymbiotic species (including the two mixotrophic species) referred to herein belong to a total pool of 32 species which derive at least part of their nutrition from chemolithotrophic production of microbial symbionts (Rodrigues et al., 2013). These numbers are remarkable and, up to now, have no match in any other cold seep region of the world.

Macrofaunal assemblages are known to respond in different ways and at different scales to structural complexity and environmental variability arising from habitat heterogeneity. Abiotic sources of heterogeneity, such as variability in fluid flow, geochemistry, and substrate type, give rise to different sets of microbial communities, microbial symbionthosting foundation species, and attendant heterotrophic assemblages; biotic sources of heterogeneity are derived from the biogenic habitats subsequently created by these species (Cordes et al., 2010b). As discussed in the previous sections, these sources of habitat heterogeneity are certainly relevant and may explain a high degree of $\beta$-diversity that has also been reported from many other cold seep regions. The specificity of the environmental conditions and putative isolation of cold seep habitats also promote a varying degree of novelty in the faunal assemblages intrinsically contributing to $\alpha$ and $\gamma$-diversity.

What are then the outstanding characteristics of the GoC?

1. The geodynamic setting of the region promotes a notorious diversity in the seep regime, and because each individual $\mathrm{MV}$ in the GoC is characterized by a particular set of environmental conditions, they act as keystone physiographic structures contributing to a stepwise accumulation of species along the depth gradient.

2. The location of GoC is central to various biogeographic regions in the Atlantic and Mediterranean, and this setting promotes the overlap of many species distributions extending their range into the GoC domain.

3. These biogeographic regions are currently interconnected by different water masses under a regional oceanographic regime with high seasonal and interannual variability likely to provide numerous options for colonization of the seabed in the GoC.

4. The geologic history of the region is long (180-160 Ma ago), and there is evidence of a much more widespread and active seepage regime in the past, which may have created a pool of evolutionary candidates for specialization to different seepage conditions.
5. Paleoclimatic changes in the oceanographic regime and the decay of past seepage activity may have augmented the distance between active seeps within the GoC while present-day oceanographic retention mechanisms are also likely to promote genetic isolation and divergence especially of those species with lower dispersal capabilities.

These factors may have different synergies at different depth ranges and overall contribute to the high $\alpha-, \beta$ and $\gamma$-diversity observed in the Gulf of Cadiz.

\section{Supplementary material related to this article is available online at: http://www.biogeosciences.net/10/ 2553/2013/bg-10-2553-2013-supplement.pdf.}

Acknowledgements. The authors acknowledge the late Mikhail Ivanov (Moscow State University) for his successful leadership of the programme Training Through Research (IOCUNESCO), which fostered much of the current knowledge on the mud volcanoes of the Gulf of Cadiz. Thanks are due to the scientific parties, officers and crews of the RV Prof. Logachev and RV Maria S. Merian for their support during the cruises TTR14, TTR15 and MSM 1/3. This work was funded by the HERMES project (EC contract number GOCE-CT-511234) under the European Commission's Framework Sixth Programme and by the HERMIONE project (contract ENV/2008/1/226354) under the European Commission's Framework Seventh Programme as well as by the R\&D programme GEOTECHNOLOGIEN funded by the German Ministry of Education and Research (BMBF) and the German Research Council (DFG), COMET project grant 03G0600D. C. F. Rodrigues, A. Hilário and A. Ravara were supported by Fundação para a Ciência e Tecnologia, grants SFRH/BPD/64154/2009, SFRH/BPD/22383/2005 and SFRH/BD/16563/2004, respectively.

Edited by: R. Serrão

\section{References}

Akhmetzhanov, A. M., Ivanov, M. K., Kenyon, N. H., and Mazzini, A. (Eds.): Deep water cold seeps, sedimentary environments and ecosystems of the Black and Tyrrhenian Seas and the Gulf of Cadiz, Preliminary results of investigations during the TTR15 cruise of RV Professor Logachev, June-August, 2005, IOC Technical Series 72, 2007.

Ambar, I., Serra, N., Brogueira, M. J., Cabeçadas, G., Abrantes, F., Freitas, P., Gonçalves, C., and Gonzalez, N.: Physical, chemical and sedimentological aspects of the Mediterranean Outflow off Iberia, Deep-Sea Res. II, 49, 4163-4177, 2002.

Bernardino, A. F., Levin, L. A., Thurber, A. R., and Smith, C. R.: Comparative composition, diversity and trophic ecology of sediment macrofauna at vents, seeps and organic falls, PLoS ONE, 7, e33515, doi:10.1371/journal.pone.0033515, 2012. 
Błażewicz-Paszkowycz, M., Bamber, R. N., and Cunha, M. R.: Apseudomorph tanaidaceans (Crustacea: Peracarida) from mudvolcanoes in the Gulf of Cadiz (North-east Atlantic), Zootaxa, 2919, 1-36, 2011a.

Błażewicz-Paszkowycz, M., Bamber, R. N., and Cunha, M. R.: New tanaidomorph Tanaidacea (Crustacea: Peracarida) from submarine mud-volcanoes in the Gulf of Cadiz (North-east Atlantic), Zootaxa, 2769, 1-53, 2011b.

Bongiorni, L., Ravara, A., Paretti; P., Rodrigues, C. F., Santos, R. S., Amaro, T., and Cunha, M. R.: Organic matter composition and macrofaunal diversity in sediments of the Condor seamount (Azores, NE Atlantic), Deep-Sea Res. II., in review, 2013.

Carney, R. S.: Consideration of the oasis analogy for chemosynthetic communities at Gulf of Mexico hydrocarbon vents, GeoMar. Lett., 14, 149-159, 1994.

Clarke, K. R. and Gorley, R. N.: Primer v6: User Manual/Tutorial, Primer-E, Plymouth, 2006.

Cordes, E. E., Becker, E. L., Hourdez, S., and Fisher, C. R.: Influence of foundation species, depth, and location on diversity and community composition at Gulf of Mexico lower-slope cold seeps, Deep-Sea Res. II, 57, 1870-1881, 2010a.

Cordes, E., Cunha, M. R., Galeron, J., Mora, C., Olu-Le-Roy, K., Sibuet, M., Van Gaever, S., Vanreusel, A., and Levin, L.: The influence of geological, geochemical, and biogenic habitat heterogeneity on seep biodiversity, Mar. Ecol., 31, 51-65, $2010 \mathrm{~b}$.

Crist, T. O., Veech, J. A., Gering, J. C., and Summerville, K. S.: Partitioning species diversity across landscapes and regions: A hierarchical analysis of $\alpha, \beta$, and $\gamma$ diversity, Am. Nat., 162, 734-743, 2003.

Cunha, M. R., Paterson, G. L. J., Amaro, T., Blackbird, S., de Stigter, H. C., Ferreira, C., Glover, A., Hilário, A., Kiriakoulakis, K., Neal, L., Ravara, A., Rodrigues, C. F., Tiago, A., and Billett, D. S. M.: Biodiversity of macrofaunal assemblages from three Portuguese submarine canyons (NE Atlantic), Deep-Sea Res. II, 58, 2433-2447, 2011.

Dando, P. R., Austen, M. C., Burke, R. A., Kendall, M. A., Kennicutt II, M. C., Judd, A. C., Moore, D. C., O'Hara, S. C. M., Schmaljohann, R., and Southward, A. J.: Ecology of a North Sea pockmark with an active methane seep. Mar. Ecol.-Prog. Ser. 70, 49-63, 1991.

Decker, C., Morineaux, M., Van Gaever, S., Caprais, J.-C., Lichtschlag. A., Gauthier, O., Andersen, A. C., and Olu, K.: Habitat heterogeneity influences cold-seep macrofaunal communities within and among seeps along the Norwegian margin. Part 1: macrofaunal community structure, Mar. Ecol., 33, 205-230, 2012.

Dworschak, P. and Cunha, M. R.: A new subfamily, Vulcanocalliacinae n. subfam., for Vulcanocalliax arutyunovi n.gen., n.sp. from a mud volcano in the Gulf of Cadiz (Crustacea, Decapoda, Callianassidae), Zootaxa, 1460, 35-46, 2007.

Foucher, J. P., Westbrook, G. K., Boetius, A., Ceramicola, S., Dupré, S., Mascle, J., Mienert, J., Pfannkuche, O., Pierre, C., and Praeg, D.: Structure and drivers of cold seep ecosystems, Oceanography, 22, 92-109, 2009.

Génio, L., Johnson, S. B., Vrijenhoek, R. C., Cunha, M. R., Tyler, P. A., Kiel, S., and Little, C. T. S.: New record of "Bathymodiolus" mauritanicus Cosel from Gulf of Cadiz (NE Atlantic) mud volcanoes, J. Shellfish Res., 27, 53-61, 2008.
Génio, L., Warén, A., Matos, F. L., and Cunha, M. R.: The snails' tale at deep-sea habitats in the Gulf of Cadiz (NE Atlantic), Biogeosciences Discuss., 10, 3707-3733, doi:10.5194/bgd-10-37072013, 2013.

Hensen, C., Nuzzo, M., Hornibrook, E., Pinheiro, L. M., Bock, B., Magalhaes, V. H., and Bruckmann W.: Sources of mud volcano fluids in the Gulf of Cadiz - indications for hydrothermal imprint, Geochim. Cosmochim. Acta, 71, 1232-1248, 2007.

Hester, K. C. and Brewer, P. G.: Clathrate hydrates in nature, Annu. Rev. Mar. Sci., 1, 303-327, 2009.

Hilário, A. and Cunha, M. R.: On some frenulate species (Annelida: Polychaeta: Siboglinidae) from mud volcanoes in the Gulf of Cadiz (Northeast Atlantic), Sci. Mar., 72, 361-371, 2008.

Hilário, A., Johnson, S. B., Vrijenhoek, R. C., and Cunha, M. R.: High diversity of frenulates (Polychaeta: Siboglinidae) in the Gulf of Cadiz mud volcanoes: a DNA taxonomy analysis, DeepSea Res. I, 57, 143-150, 2010.

Hurlbert, S. H.: The nonconcept of species diversity: a critique and alternative parameters, Ecology, 52, 577-585, 1971.

Jumars, P. A. and Wheatcroft, R. A.: Responses of benthos to changing food quality and quantity, with a focus on deposit feeding and bioturbation, in: Productivity of the Ocean: Present and Past, edited by: Berger, W. H., Smetacek, V. S., and Wefer, G., Wiley, Chichester, 235-253, 1989.

Juniper, S. K. and Sibuet, M.: Cold seep benthic communities in Japan subduction zones: spatial organization, trophic strategies and evidence for temporal evolution, Mar. Ecol.-Prog. Ser., 40, 115-126, 1987.

Kenyon, N. H., Ivanov, M. K., Akhmetzhanov, A. M., and Kozlova, E. V. (Eds.): Interdisciplinary Geoscience Studies of the Gulf of Cadiz and Western Mediterranean basins, Preliminary results of investigations during the TTR-14 cruise of RV Professor Logachev, July-September, 2004, Paris, France, IOC Technical Series, 70, 115 pp., appendices 31-37, 2006.

Larsen, K.: Deep-sea Tanaidacea (Peracarida) from the Gulf of Mexico, Crustacean Monographs, 5. Brill, Leiden, 2005.

Levin, L. A.: Ecology of cold seep sediments: Interactions of fauna with flow, chemistry and microbes, Oceanogr. Mar. Biol., 43, 146, 2005.

Levin, L. A. and Mendoza, G. F.: Community structure and nutrition of deep methane-seep macrobenthos from the North Pacific (Aleutian) Margin and the Gulf of Mexico (Florida Escarpment), Mar. Ecol., 28, 131-151, 2007.

Levin, L. A. and Sibuet, M.: Understanding continental margin biodiversity: A new imperative, Annu. Rev. Mar. Sci., 4, 79-112, 2012.

Levin, L. A., Ziebis, W., Mendoza, G., Growney, V., Tryon, M., Brown, K., Mahn, C., Gieskes, J., and Rathburn, A. E.:. Spatial heterogeneity of macrofauna at northern California methane seeps: the influence of sulfide concentration and fluid flow, Mar. Ecol.-Prog. Ser. 265, 123-139, 2003.

Levin, L. A., Mendoza, G. F., Gonzalez, J. P., Thurber, A. R., and Cordes, E. E.: Diversity of bathyal macrofauna on the northeastern Pacific margin: the influence of methane seeps and oxygen minimum zones, Mar. Ecol., 31, 94-110, 2010.

Levin, L. A., Orphan, V. J., Rouse, G. W., Ussler, W., Rathburn, A. E., Cook, G. S., Goffredi, S., Perez, E., Waren, A., Grupe, B., Chadwick, G., and Strickrott. B.: A hydrothermal seep on the Costa Rica margin: Middle ground in a continuum of reducing 
ecosystems, Proc. Biol Sci., 279, 2580-2588, 2012.

Magalhães, V. H., Pinheiro, L. M., Ivanov, M. K., Kozlova, E., Blinova, V., Kolganova, J., Vasconcelos, V., McKenzie, J. A., Bernasconi, S. M., Kopf, A. J., Díaz-del-Río, V., González, F. J., and Somoza, L.: Formation processes of methane-derived authigenic carbonates from the Gulf of Cadiz, Sediment. Geol., 243244, 155-168, 2012.

Magurran, A. E.: Measuring biological diversity, Blackwell Publishing, 2004.

Menot, L., Galeron, J., Olu, K., Caprais, J.-C., Crassous, P., Khripounoff, A., and Sibuet, M.: Spatial heterogeneity of macrofaunal communities in and near a giant pockmark area in the deep Gulf of Guinea, Mar. Ecol., 31, 78-93, 2010.

Moura, C. J., Cunha, M. R., Porteiro, F. M., Yesson, C., and Rogers, A. D.: Evolution of Nemertesia hydroids (Cnidaria: Hydrozoa, Plumulariidae) from the shallow and deep waters of the NE Atlantic and W Mediterranean, Zool. Scr. 41, 79-96, 2012.

Moura, C. J., Cunha, M. R., Porteiro, F. M., and Rogers, A. D.: Polyphyly and cryptic diversity in the hydrozoan families Lafoeidae and Hebellidae (Cnidaria: Hydrozoa), Invertebr. Syst., 25, 454 470, 2011

Niemann, H., Duarte, J., Hensen, C., Omoregie, E., Magalhães, V.H., Elvert, M., Pinheiro, L., Kopf, A., and Boetius, A.: Microbial methane turnover at mud volcanoes of the Gulf of Cadiz, Geochim. Cosmochim Ac., 70, 5336-5335, 2006.

Nuzzo, M., Hornibrook, E. R. C., Gill, F., Hensen, C., Pancost, R. D., Haeckel, M., Reitz, A., Scholz, F., Magalhães, V. H., Brueckmann, W., and Pinheiro, L. M.: Origin of light volatile hydrocarbon gases in mud volcano fluids, Gulf of Cadiz - Evidence for multiple sources and transport mechanisms in active sedimentary wedges, Chem. Geol., 266, 359-372, 2009.

Oliver, P. G., Rodrigues, C. F., and Cunha, M. R.: Chemsymbiotic bivalves from the mud violcanoes of the Gulf of Cadiz, with descriptions of new species of Solemyidae, Lucinidae and Vesicomyidae, Zookeys, 113, 1-38, 2011.

Olu-Le Roy, K., Sibuet, M., Fiala-Médioni, A., Gofas, S., Salas, C., Mariotti, A., Foucher, J.-P., and Woodside, J.: Cold seep communities in the deep eastern Mediterranean Sea: composition, symbiosis and spatial distribution on mud volcanoes, Deep-Sea Res. I, 51, 1915-1936, 2004.

Paull, C. K., Hecker, B., Commeau, R., Freemanlynde, R. P., Neumann, C., Corso, W. P., Golubic, S., Hook, J. E., Sikes, E., and Curray, J.: Biological communities at the Florida Escarpment resemble hydrothermal vent taxa, Science, 226, 965-967, 1984.

Pielou, E. C.: An Introduction to Mathematical Ecology. WileyInterscience, New York, 1969.

Pinheiro, L. M., Ivanov, M. K., Sautkin, A., Akhmanov, G., Magalhães, V. H., Volkonskaya, A., Monteiro, J. H., Somoza, L., Gardner, J., Hamouni, N., and Cunha, M. R.: Mud volcanism in the Gulf of Cadiz: results from the TTR-10 cruise, Mar. Geol., 195, 131-151, 2003.

Quentel, E., Carton, X., and Gutscher, M. A.: Structure and temporal variability of Mediterranean water in hydrological and marine seismic data South of Portimão Canyon (Gulf of Cadiz), from 1999 to 2002, Int. J. Geosci., 2, 185-194, 2011.

Rex, M. A., Etter, R. J., Morris, J. S., Crouse, J., McClain, C. R., Johnson, N. A., Stuart, C. T., Thies, R., and Avery, R.: Global bathymetric patterns of standing stock and body size in the deepsea benthos, Mar. Ecol.-Prog. Ser., 317, 1-8, 2006.
Ritt, B., Desbruyères, D., Caprais, J.-C., Gauthier, O., Ruffine, L., Buscail, R., Olu-Le Roy, K., and Sarrazin, J.: Seep communities from two mud volcanoes in the deep eastern Mediterranean Sea: faunal composition, spatial patterns and environmental control, Mar. Ecol.-Prog. Ser., 466, 93-119, 2012.

Rodrigues, C. F., Oliver, P. G., and Cunha, M. R.: Thyasiroidea (Mollusca: Bivalvia) from the mud volcanoes of the Gulf of Cadiz (North-east Atlantic), Zootaxa, 1752, 41-56, 2008.

Rodrigues, C. F., Webster, G., Cunha, M. R., and Weightman, A. J.: Chemosynthetic bacteria found in bivalve species from mud volcanoes of the Gulf of Cadiz, FEMS Microbiol. Ecol., 73, 488499, 2010.

Rodrigues, C. F., Hilário, A, Cunha, M. R., Weightman, A. J. and Webster, G.: Microbial diversity in Frenulata (Siboglinidae, Polychaeta) species from mud volcanoes in the Gulf of Cadiz (NE Atlantic), edited by: van Leeuw, A., J. Microbiol., 100, 8398, 2011a.

Rodrigues, C. F., Paterson, G. L. J., Cabrinovic, A., and Cunha M. R.: Deep-sea ophiuroids (Echinodermata) from mud volcanoes in the Gulf of Cadiz (NE Atlantic), Zootaxa, 2754, 1-26, 2011b.

Rodrigues, C. F., Hilário, A., and Cunha, M. R.: Chemosymbiotic species from the Gulf of Cadiz (NE Atlantic): distribution, life styles and nutritional patterns, Biogeosciences, 10, 2569-2581, doi:10.5194/bg-10-2569-2013, 2013

Sallarès, V., Gailler, A., Gutscher, M.-A., Graindorge, D., Bartolomé, R., Gràcia, E., Díaz, J., Dañobetia, J. J., and Zitellini, N.: Seismic evidence for the presence of Jurassic oceanic crust in the central Gulf of Cadiz (SW Iberian margin), Earth Planet. Sc. Lett., 311, 112-123, 2011.

Sahling, H., Rickert, D., Lee, R. W., Linke, P., and Suess, E.: Macrofaunal community structure and sulfide flux at gas hydrate deposits from the Cascadia convergent margin, Mar. Ecol.-Prog. Ser., 231, 121-138, 2002.

Sahling, H., Galkin, S. V., Salyuk, A., Greinert, J., Foerstel, H., Piepenburg, D., and Suess, E.: Depth-related structure and ecological significance of cold-seep communities: a case study from the Sea of Okhotsk, Deep-Sea Res. I, 50, 1391-1409, 2003.

Scholz, F., Hensen, C., Reitz, A., Romer, R. L., Liebetrau, V., Meixner, A., Weise, S. M., and Haeckel, M.: Isotopic evidence for alteration of the oceanic crust at deep-rooted mud volcanoes in the Gulf of Cadiz, NE Atlantic Ocean, Geochim. Cosmochim. Ac., 73, 5444-5459, 2009.

Scholz, F., Hensen, C., Lu, Z., and Fehn, U.: Controls on the ${ }^{129} \mathrm{I} / \mathrm{I}$ ratio of deep-seated marine interstitial fluids: "Old" organic versus fissiogenic 129-iodine, Earth Planet. Sc. Lett., 294, 27-36, 2010.

Sibuet, M. and Olu, K.: Biogeography, biodiversity and fluid dependence of deep-sea cold-seep communities at active and passive margins, Deep-Sea Res. II, 45, 517-67, 1998.

Smith, C. R., De Leo, F. C., Bernardino, A. F., Sweetman, A. K., and Martinez Arbizu, P.: Abyssal food limitation, ecosystem structure and climate change, Trends Ecol. Evol., 23, 518-528, 2008.

Snelgrove, P. V. R. and Smith, C. R.: A riot of species in an environmental calm: the paradox of species-rich deep-sea floor. Oceanog, Mar. Biol. Ann. Rev., 40, 311-342, 2002.

Sommer, S., Linke, P., Pfannkuche, O., Schleicher, T.,. Schneider v. Deimling, Reitz, A., Haeckel, M., Flögel, S., and Hensen, C.: Seabed methane emissions and the habitat of frenulate tubeworms on the Captain Arutyunov mud volcano (Gulf of Cadiz), 
Mar. Ecol.-Prog. Ser., 382, 69-86, 2009.

Stadnitskaia, A., Ivanov, M. K.., Blinova, V., Kreulen, R., and van Weering, T. C. E.: Molecular and carbon isotopic variability of hydrocarbon gases from mud volcanoes in the Gulf of Cadiz, NE Atlantic, Mar. Petrol. Geol., 23, 281-296, 2006.

Suess, E., Carson, B., Ritger, S. D., Moore, J. C., Kulm, L. D., and Cochrane, G. R.: Biological communities at vent sites along the subduction zone off Oregon, Bull. Biol. Soc. Washington, 6, 475-484, 1985.

Thiebot, E. and Gutscher, M. A.: The Gibraltar Arc seismogenic zone (part 1): constraints on a shallow east dipping fault plane source for the 1755 Lisbon earthquake provided by seismic data, gravity and thermal modeling, Tectonophysics 426, 135-152, 2006.

Van Aken, H. M.: The hydrography of the middlelatitude Northeast Atlantic Ocean II: The intermediate water masses, Deep-Sea Res. I, 47, 789-824, 2000.

Van Rensbergen, P., Depreiter, D., Pannemans, B., Moerkerke, G., Van Rooij, D., Marsset, B., Akhmanov, G., Blinova, V., Ivanov, M., Rachidi, M., Magalhães, V., Pinheiro, L., Cunha M., and Henriet J.-P.: The El Arraiche mud volcano field at the Moroccan Atlantic slope, Gulf of Cadiz, Mar. Geol., 219, 1-17, 2005.

Vanneste, H., Kelly-Gerreyn, B. A., Connelly, D. P., James, R.H., Haeckel, M., Fisher, R. E., Heeschen, K., and Mills, R. A.: Spatial variation in fluid flow and geochemical fluxes across the sediment-seawater interface at the Carlos Ribeiro mud volcano (Gulf of Cadiz), Geochim. Cosmochim. Ac., 75, 1124-1144, 2011.

Vanneste, H., Kastner, M., James, R. H., Connelly, D. P., Fisher, R. E., Kelly-Gerreyn, B. A., Heeschen, K., Haeckel, M., and Mills, R. A.: Authigenic carbonates from the Darwin Mud Volcano, Gulf of Cadiz: A record of palaeo-seepage of hydrocarbon bearing fluids, Chem. Geol., 300-301, 24-39, 2012.
Vanreusel, A., Andersen, A.C., Boetius, A., Connelly, D., Cunha, M. R., Decker, C., Hilario, A., Kormas, K. A., Maignien, L., Olu, K., Pachiadaki, M., Ritt, B., Rodrigues, C., Sarrazin, J., Tyler, P., Van Gaever, S., and Vanneste, H.: Biodiversity of cold seep ecosystems along the European margins, Oceanography, 22, 110-127, 2009.

Wagner, H. H., Wildi, O., and Ewald, K. C.: Additive partitioning of plant species diversity in an agricultural mosaic landscape, Landscape Ecol., 15 219-227, 2000.

Wienberg, C., Hebbeln, D., Fink, H. G., Mienis, F., Dorschel, B., Vertino, A., López Correa, M., and Freiwald, A.: Scleractinian cold-water corals in the Gulf of Cadiz - First clues about their spatial and temporal distribution, Deep-Sea Res. I, 56, 1873 1893, 2009.

Wehrmann, L. M., Templer, S. P., Brunner, B., Bernasconi, S. M., Maignien, L., and Ferdelman, T. G.: The imprint of methane seepage on the geochemical record and early diagenetic processes in cold-water coral mounds on Pen Duick Escarpment, Gulf of Cadiz, Mar. Geol., 282, 118-137, 2011.

Zitellini, N., Gràcia, E., Matias, L., Terrinha, P., Abreu, M. A., De Alteriis, G., Henriet, J.P., Dañobeitia, J. J., Masson, D. G., Mulder, T., Ramella, R., Somoza, L., and Diez, S.: The quest for the Africa-Eurasia plate boundary west of the Strait of Gibraltar, Earth Planet. Sc. Lett., 280, 13-50, 2009. 